\title{
EXERCISE OF POWERS OF APPOINTMENT: SHOULD INTENT TO EXERCISE BE INFERRED FROM A GENERAL DISPOSITION OF PROPERTY?
}

\author{
Susan F. French*
}

Powers of appointınent are devices used in estate planning to postpone selection of the recipients of the donor's property until some time after the date of the gift. ${ }^{1}$ Such a power may be retained by the donor or granted to another. In either case, the holder of the power is called the "donee,"2 who inay select the recipient of the property through an "exercise" or "execution" of the power. Exercise of a power requires some expression of the donee's intent to exercise in an imstrument of the sort specified by the donor in the original gift. ${ }^{3}$ Donors typically

* Professor of Law, University of California, Davis; A.B. 1964, Stanford University; J.D. 1967, University of Washington.

THE FOLLOWING CITATIONS WILL BE USED IN THIS ARTICLE:

5 American Law of Property (A.J. Casner ed. 1952) [hereinafter cited as 5 American LAW OF PROPERTY];

Restatement of Property (1940) [hereinafter cited as Restatement];

E. Sugden, A Practical Treatise of Powers (8th ed. 1861) [hereinafter cited as Sugden];

J. Wigmore, A Treatise on the Anglo-American System of Evidence in Trials at COMMON LAW (3d ed. 1940) [hereinafter cited as WiGMore].

1. Through their ability to postpone this selection process, powers of appointment introduce flexibility into the dispositive provisions of long-term trusts. See, e.g., A. CASNER, Estate PLANNing 689-782 (3d ed. 1961); J. Trachtman, Estate Planning 201-11 (1968); H. Tweed \& W. Parsons, Lifetime and Testamentary Estate Planning 71-74 (8th ed. 1978); Halbach, The Use of Powers of Appointment in Estate Planning, 45 lowa L. Rev. 691 (1960).

2. The terminology employed in this Article generally follows that of the Restatement of Property. A power of appointment is a power to designate the transferees of property or the shares annong designated transferees, within limits specified by the creator of the power. A general power is one that can be exercised in favor of the donee or the donee's estate; a special power is one to appoint to or among the inembers of a group not unreasonably large. The creator of the power is the "donor," the holder of the power is the "donee," and the permissible appointees are the "objects" of the power. Finally, the donor nay name a "taker in default," who receives the property should the donee fail to exercise the power. RESTATEMENT $\$ \$ 318-320$.

3. 5 american Law of Property \& 23.37; 3 R. Powell, Real Property 1796 (P. Rohan rev. ed. 1979); Restatement, Introductory Note to Topic 6, at 1904; L. Simes \& A. SMITH, THE LAW OF FUTURE INTERESTS $\$ \S 972-973$ (2d ed. 1956). 
require exercise by deed or by will. ${ }^{4}$

When the donee holds a testamentary power, that is, a power exercisable by will, the courts often face a serious problem in determining whether his will manifests an intent to exercise the power. If the will does not specifically inention the power, but disposes of the donee's property only in general terms or through a residuary clause, his imtent as to exercise is unclear. For example, a donor may convey property to trustees to hold for the benefit of the donee for life, then to distribute the remainder as the donee shall appoint by will, and, in default of appointment, to the donor's children. ${ }^{5}$ The donee dies testate, and his will states only, "I give all iny property to $R$." The donee inay have intended that the property subject to the power pass to $R$ with the rest of the donee's estate; on the other hand, the donee may have intended that only his own property go to $R$, and that the appointive property go to the takers in default of appointment, the donor's children. Since 1599, English and American courts and legislatures have been troubled by this problein and have attempted to resolve the issue in various ways. ${ }^{6}$ None of these solutions, however, has proved wholly satisfactory.

Part I of this Article analyzes the nature of the problem presented by a testamentary disposition that inay or inay not have been intended to exercise the power of appointment and sets forth in summary form the various approaches to the problem currently employed in American jurisdictions. Part II then traces the development of judicial responses to the problein froin 1599 to the 1830s, when dissatisfaction with the case law led to statutory reform. Part III discusses the statutes of the 1830 s, concluding that they created the same kind of problem as did the prior case law. To demonstrate the inadequacy of these reform statutes, Part IV presents a sample of the cases decided under thein and concludes that neither the pre-1830 case law nor the reform statutes provided a satisfactory solution to the problein, as both refused to perinit consideration of any evidence extrimsic to the will in determining whether the donee intended to exercise the power. Part V then traces and analyzes the development of the American common law in those states that did not enact reform statutes. Part VI deals with modern statutes governing whether a general residuary clause exercises a power

4. The donor may also specify a less formal means of exercise, such as a letter addressed to the trustee.

5. If created by the donor's will, this would be a typical marital deduction trust provision. See TWEed \& PARsons, supra note 1 , at 61.

6. The question of exercise by means other than a direct statement reciting the existence of the power and the intent to exercise apparently first arose in Sir Edward Clere's Case, 77 Eng. Rep. 279 (K.B. 1599). 
of appointment. Discussion of these statutes, together with the discussion of the American common law in Part V, forms the basis for the solution outlined im Part VII. The Article concludes with a proposal for nationwide enactment of this solution, suggesting that uniformity among jurisdictions is a prerequisite to a wholly satisfactory solution.

\section{Analysis of the Problem and Summary of Current SOLUTIONS}

The power of appointinent separates the power to dispose of property from the basic ownership of the property. ${ }^{7}$ The device makes the power to dispose completely independent of ownership, giving the donee the advantage of the power to dispose without the liabilities of property ownership. ${ }^{8}$ From this essential character of the power of appointenent stems the requirement that exercise of the power occur only as the result of a volitional act by the donee. Unless the donee acts to exercise the power, the ownership of the property contimues undisturbed. 9 For exainple, a donor might transfer property to trustees to pay income to her parent for life, then to distribute the primcipal as her spouse appoints by deed or will, and, in default of appointment, to a named charity. The spouse, the donee of the power, has no ownership interest im the trust property, having only the power to dispose of the remainder. Despite the label "taker in default," the named charity is the owner of the remainder, which is regarded as vested subject to di-

7. General discussions of the nature and operation of powers of appointment inay be found in 5 AMERICAN LAW of PRoperty \$ 23.1; 3 Powell, supra note 3, I 385; Simes \& SMITH, supra note $3, \S 861$.

8. An obvious liability of ownership is that the assets are available to creditors. Ownership of a special power does not subject the appointive property to the donee's creditors because the donee has no beneficial interest. RESTATEMENT $\$ 326$. In the absence of a statute, creditors of the holder of a general power cannot reach the appointive property unless the donee has exercised the power. Quinn v. Tuttle, 104 N.H. 1, 3, 177 A.2d 391, 393 (1962); REsTATEMENT § 327. Where the donee lias exercised a general power, the courts are divided: the majority position is that the assets may be reached to satisfy the donee's debts. RESTATEMENT $\$ \$ 329-330$. This inay be true even if the appointment is defective. Gilman v. Bell, $99 \mathrm{lll}$. 144, 149 (1881). A minority of courts refuse to allow the donee's creditors to reach the assets unless the assets are appointed to the decedent's estate. See, e.g., St. Matthews Bank v. De Charette, 259 Ky. 802, 817, 83 S.W.2d 471, 478 (1935). See also Annot., 97 A.L.R. 1070 (1935); Annot., 59 A.L.R. 1510 (1929).

9. Most powers of appointment are entirely discretionary with the donee. 5 AMERICAN LAW OF PROPERTY \$ 23.37. Some special powers have been labeled "imperative" or "powers in trust." When the donee lias failed to exercise a special power, and the donor has failed to include an express gift in default, the appointive property will nevertheless pass to the objects of the special power nained in the donor's will. See, e.g., Daniel v. Brown, 156 Va. 563, 159 S.E. 209 (1931); Gray, Powers in Trust and Gifts Implied in Default of Appointment, 25 HARv. L. REv. 1 (1911). This Article is not concerned with cases in which the exercise of the power is not dependent on any intent of the donee to exercise. 
vestment by exercise of the power. ${ }^{10}$ Until the donee chooses to exercise the power, the charity remains the owner. A power of appointment is personal to the donee and expires at his death. If the donee dies without having exercised the power, the charity's ownership becomes absolute. ${ }^{11}$ Because the donee is not the owner of the appointive assets, they will not descend on his death to his intestate successor, ${ }^{12}$ nor will they pass under a disposition of property $\mathrm{m}$ his will unless the will exercises the power. ${ }^{13}$

Assuming the donee has the power to appoint by will, the question whether the will exercises the power depends on the donee's imtent. In some cases the donee's intent is unmistakably clear. When the donee's will recites the existence of the power, describes the property subject to the power, and then states that the donee does or does not intend to exercise the power, no question arises as to the donee's intent. If such a will is properly executed and the named appointee is alive and is a permissible appointee, the donee's intent is given effect. ${ }^{14}$

In a second class of cases, it is possible to infer whether the donee intended to exercise the power. When the donee's will does not mention the power, but disposes of the property subject to the power, the donee clearly imtends to execute the power. For example, if the donee's will devises Blackacre to $X$ when the donee has only a power over Blackacre, it is clear that the donee intended to exercise the power by his will. The donee's intent is equally obvious when his will disposes only of property that is unmistakably his own. For example, if a donee owning Blackacre devises it to $X$ and makes no other disposition in his will, the will demonstrates no imtent to exercise the donee's power over any appoimtive property. ${ }^{15}$

In a third category of cases, however, the donee's intent is not clearly inferable from the language of his will as applied to his estate. In these situations the donee's will typically makes a disposition of property similar to the appoimtive property but does not refer to the existence of the power. Further, the donee may own or might have

10. Willis v. Martin, 100 Eng. Rep. $882,896-97$ (K.B. 1790).

11. SIMES \& SMITH, supra note 3, § 943. The property is relieved of the burden of the power that, had it been exercised, would have divested the interest of the taker in default.

12. 5 american Law of Property \& 23.62; see Restatement \& 367.

13. See Restatement \& 343.

14. For a discussion of the problems presented when the appointee predeceases the donee, see French, Application of Antilapse Statutes to Appointments Made By Will, 53 WASH. L. REv. 405 (1978).

15. No inference of intent to exercise a power can be drawn froun the disposition of property that is clearly not subject to the power and that the donee disposes of by virtue of ownership of the property. See Simes \& SMrTH, supra note 3, § 973. 
owned property, aside from that subject to the power, that passes or could have passed under the will. Cases involving such dispositions range from a bequest of stock in a named corporation to a disposition of "all real and personal estate" of the donee. ${ }^{16}$ In such situations the disposition in the donee's will may or may not apply to the property subject to the power. The legatees or devisees under the donee's will claim the appointive assets as appoimtees; the donor or the donor's transferees claim the property as takers im default. ${ }^{17}$ Proper resolution of their conflicting claims depends on whether the donee intended the disposition of property im his will to exercise the power.

Resolution of the conflicting claims of the takers in default and the takers under the donee's will is determined by three factors: the basic assumption the court makes in deciding whether a general disposition in the donee's will is intended to exercise the power; the extent to which extrinsic evidence of the donee's intent will be admitted; and the amount or quahity of evidence required to overcoine the basic assuinption. Early $\mathrm{m}$ the development of the common law of powers, the English courts created the assumption that a disposition of the appointive property without reference to the power was not intended to execute the power. ${ }^{18}$ The only extrinsic evidence they admitted was of the assets owned by the donee at the time the will was executed, and such evidence could support an inference of intent to exercise the power only when the evidence was conclusive. ${ }^{19}$ In a number of cases, the English courts reached results that clearly frustrated the donee's intent.

Dissatisfaction with these cases led to enactment of reform statutes

16. The most common situations are those in which the donee's will contains a residuary clause or a clause disposing of all the donee's property. Since the property disposed of is described in such general terms as "estate" or "property," it could include the property subject to the power, or equally well not include it. Less frequently, the anbiguity may appear in the provision for a legacy. See 5 American Law of Property \$\& 23.39-.40; 3 Powell, supra note 3, ๆ 397; Simes \& SMITH, supra note $3, \S 973$.

17. The donor will ordinarily transfer the interests in default of appointment by the sane instrument that created the power. However, if the power is created by an inter vivos instrument that makes no gift in default of the appointment, the donor retains the interest subject to the power (which would ordinarily be a reversion). On the death of the donor, this interest would pass to her successors, testate or intestate.

18. Powers of appointment have been used simce at least the latter half of the fifteenth century. Berger, The General Power of Appointment as an Interest in Property, 40 NEB. L. REv. 104, 107 (1960); Powell, Powers of Appointment, 10 BRookLyN L. Rev. 233 (1941). Sir Edward Clere's Case, 77 Eng. Rep. 279 (K.B. 1599), discussed in notes 42-45 infra and accompanying text, was the first to decide that anything other than an express reference to the power could result in exercise. The requirement of affirmative action to exercise the power follows from the fact that the power is different from ownership of the property. See text accompanying notes 7-9 supra.

19. See notes 42-103 infra and accompanying text. 
in England and New York in the 1830s. ${ }^{20}$ These statutes reversed the basic assumption, providing that a general disposition of property by the donee would exercise a power of appointment. The English statute applied only to general powers; the New York statute applied to all powers. Several American states enacted statutes based on one or the other of these models. ${ }^{21}$ Under both of these statutes, all extrinsic evidence of the donee's imtent was excluded, even that which would have been permitted under the prior case law. ${ }^{22}$ Again the result has been frustration of the donees' intent.

American jurisdictions that did not enact statutes based on the 1830s reforms liave retained the basic assumption that a general disposition or residuary clause is not intended to exercise the power. The case law of these states differs, however, from the pre-1830 case law in that extrimsic evidence of the circumstances surrounding execution of the donee's will is admissible. Because these states had no controlling statutes, the courts were able to follow contemporary trends in imterpretation of wills, which had led to the general admissibility of extrinsic evidence by the early $1800 \mathrm{~s}^{23}$ Although the results in these jurisdictions are generally better than those in jurisdictions with statutes based on the 1830s reforins, a simple repeal of those statutes and a return to the common law will not provide a satisfactory solution. There are significant differences among American common law rules governing the kinds of extrinsic evidence that are adımissible, ${ }^{24}$ and, more impor-

20. I N.Y. Rev. Stats. pt. II, ch. 1, tit. 2, § 126 (1836); Wills Act of 1837,7 Will. 4 \& 1 Vict., c. $26, \S 27$.

21. See notes 128-31 infra and accompanying text.

22. The English statute expressly provided that a general devise or bequest would exercise a general power "unless a contrary Intention shall appear by the Will." 7 Will. 4 \& 1 Vict., c. 26 , $\S 27$ (1837). The language of the New York statute was that the general devise would exercise the power "unless the intent that the will shall not operate as an execution of the power, shall appear, expressly or by necessary implication." I N.Y. Rev. Stats. pt. II, ch. 1, tit. 2, § 126 (1836). Lockwood v. Mildeburger, 159 N.Y. 181, 53 N.E. 803 (1899), held that any "necessary implication" must be from the language of the will, not from extrinsic circumstances.

23. J. Thayer, A Preliminary TReatise on Evidence at the Common Law 445 (1898); 9 WIGMORE \& 2470.

24. The principal difference concerning the admissibility of extrinsic evidence arises over direct declarations of the testator's intent. The majority of jurisdictions exclude such declarations-creating an exception to the general rule of admissibility of evidence of circumstances surrounding execution of the will-unless there is an "equivocation" or, in the language of Lord Bacon, a "Iatent ambiguity," in which case there is an exception to the exception, and the direct declarations of intent are admissible to resolve the ambiguity. 4 W. Bowe \& D. PARKER, PAGE ON WILLS $§ 32.9$ (rev. ed. 1961); RESTATEMENT \& 242, Comment j; 9 WIGMORE § 2471. A minority of jurisdictions admit evidence of direct declarations of the testator's intent regardless of the presence of an equivocation. See, e.g., Smith v. Nelson, 249 Ala. 51, 29 So. 2 d 335 (1947); Northern Trust Co. v. Cudahy, 339 Ill. App. 603, 91 N.E.2d 607 (1950) (statements could be used to show what the words meant, but not what the testator intended to write); Wilson v. Flowers, 58 N.J. 250, 277 A.2d 199 (1971). 
tantly, governing the strength or quality of the evidence necessary to support an inference of intent to exercise the power. Some jurisdictions insist that the evidence be so strong that no other inference can fairly be drawn, while others require only a preponderance of the evidence to support an inference of intent to exercise. ${ }^{25}$

During the 1960s and 1970s, a number of American states adopted new statutes because of clianges in the tax laws. ${ }^{26}$ These new statutes ${ }^{27}$ generally operate agaimst any inference of intent to exercise, either by codifying the common law assumption that a general disposition of property is not intended to exercise a power, or by reversing a prior statutory assumption favoring exercise. Some, but not all, of these new statutes permit consideration of extrinsic evidence of the donee's intent. None of thein addresses the question whether declarations of the donee's intent are admissible, and none of them specifies the amount or quality of evidence required to support an inference that the donee imtended to exercise her power.

Today there are statutes in twenty-nine states that create a basic assumption as to whether a general disposition of property or a residuary clause in the donee's will is, in the absence of other evidence, sufficient manifestation of intent to exercise the power. ${ }^{28}$ Four of these statutes give an unqualified yes: the residuary clause exercises the power. ${ }^{29}$ Eight of the statutes answer yes, but only if the power is a general power. ${ }^{30}$ Three of the statutes give a highly qualified yes: the residuary clause exercises the power only if the power is general and only if there is no express gift in default in the mstrument creating the power. ${ }^{31}$ Of these statutes, all but California's, and perliaps Wiscon-

The California Probate Code appears to exclude the use of a testator's oral declarations to correct imperfect or ambiguous descriptions. CaL. Prob. Code $\$ 105$ (West 1956). However, it has been held not to exclude the testator's instructions to the scrivener. In re De Moulin's Estate, 101 Cal. App. 2d 221, 225 P.2d 303 (1950).

25. See text accompanying notes 199-215 infra.

26. See notes 220-24 infra and accompanymg text.

27. See note 225 infra and accompanying text.

28. Recently enacted statutes are discussed im detail at notes 225-74 infra and accompanymg text.

29. Ky. Rev. Stat. § 394.060 (1970); N.Y. Est., Powers \& Trusts LAw $\$ 10-6.1$ (McKinney 1967); Okla. STAT. ANN. tit. 84, § 164 (West 1970); S.D. CoMPILEd Laws ANN. § 29-5-24 (1976).

30. Cal. Civ. Code $\$ 1386.2$ (West Cum. Supp. 1978); D.C. Code EncyCL. $§ 18-303$ (West 1967); N.C. Gen. Stat. § 31-43 (1976); 20 Pa. Cons. STat. ANN. § 2514(14) (Purdon 1975); R.I. GEN. LAWS § 33-6-17 (1969); S.C. CODE § 21-7-430 (1976); VA. CODE § 64.1-67 (1973); W. VA. CODE § 41-3-6 (1966).

31. Mo. Est. \& Trusts Code AnN. § 4-407 (1974); Mich. Comp. Laws ANn. § 556.114 (Cum. Supp. 1978-79); Wis. STAT. ANN. \& 702.03(2) (West 1978). 
sin's, prevent consideration of extrinsic evidence of the donee's intent. ${ }^{32}$ Fourteen statutes answer no: the residuary clause alone does not exercise the power..$^{33}$ None of these statutes prevents consideration of extrinsic evidence. In the twenty-one states in which there are no statutes, the answer is also no. ${ }^{34}$

The possibilities for confusion and mistake inherent in the number of different rules on whether and under what circumstances a general disposition or residuary clause exercises a power of appointment have been compounded by the traditional choice of law rule. Under the traditional rule, the question whether the donee's will exercises the power is governed by the law of the state that governs interpretation of the instrument that created the power, usually the law of the donor's domicile or of the situs of the trust. ${ }^{35}$ Lawyers may easily overlook the fact that the law determining whether the donee's will exercises the power is not that of the donee's domicile or of the state where the will is executed. ${ }^{36}$ Although the modern dominant interest approach ${ }^{37}$ might

32. See notes 238-58 \& 264-74 infra and accompanying text.

33. Alaska Stat. § 13.11.265 (1972); Ariz. Rev. Stat. § 14-2610 (1975); Colo. Rev. Stat. $\S \S 15-2-303,11-610$ (1973); FLA. STAT. ANN. $\S 732.607$ (West 1976); 1976 Haw. Sess. Laws, act 200, § 2-610; IDAHo CODE § 15-2-610 (1979); MAss. Gen. LAws ANN. ch. 191, § 1A (West Cum. Supp. 1978-79); Minn. Stat. ANN. \& 524.2-610 (West 1978); Mont. Rev. Codes ANN. § 91A-2610 (1975); Neb. Rev. Stat. § 30-2348 (1975); N.M. Stat. ANN. § 32A-2-610 (1976); N.D. CeNT. Code $§ 30.1-09-10$ (1976); OR. Rev. STAT. § 112.410 (1975); UtAH Code ANN. § 75-2-610 (1977).

34. United States v. Merchants Nat'l Bank, 261 F.2d 570 (5th Cir. 1958); Harrison v. Lee, 3 F.2d 796 (5th Cir. 1925); Mastin v. Merchants Nat'l Bank, 278 Ala. 261, 177 So. $2 \mathrm{~d} 817$ (1965); Welch v. Tarver, 256 Ark. 272, 507 S.W.2d 505 (1974); DiSesa v. Hickey, 160 Conn. 250, 278 A.2d 785 (1971); Carlisle v. Delaware Trust Co., 34 Del. Ch. 133, 99 A.2d 764 (1953); May v. Citizens \& S. Bank, 223 Ga. 614, 157 S.E.2d 279 (1967); Northern Trust Co. v. House, 3 Ill. App. 2d 10, 120 N.E.2d 234 (1954); Crawfordsville Trust Co. v. Elston Bank \& Trust Co., 216 Ind. 596, 25 N.E.2d 626 (1940); Crecelius v. Sinith, 255 lowa 1249, 125 N.W.2d 786 (1964); Seltzer v. Schroeder, 409 S.W.2d 777 (Mo. App. 1966); Faulkner v. Faulkner, 93 N.H. 451, 44 A.2d 429 (1945); Pennsylvania Co. for Ins. on Lives \& Granting Annuities v. Morrell, 108 N.J. Eq. 188, 154 A. 416 (1931); King v. Richardson, 7 Tenn. App. 535 (1928) (inter vivos disposition effective because otherwise inoperative); Republic Nat'1 Bank v. Fredericks, 155 Tex. 79, 283 S.W.2d 39 (1955); of. Sinke v. Muncie, 110 Kan. 345, 203 P. 1102 (1922) (instrument otherwise inoperative will exercise power); Bar Harbor Banking \& Trust Co. v. Preachers' Aid Soc'y of the Methodist Church, 244 A.2d 558 (Me. 1968) (intent to exercise found from evidence extrinsic to the will); RESTATEMENT $\S 343$.

The law of Ohio is sonnewhat uncertain, but it appears that a residuary clause will not exercise a power in that state. Compare Kiplinger v. Armstrong, 34 Ohio App. 348, 171 N.E. 245 (1930) with Dollar Sav. \& Trust Co. v. First Nat'l Bank, 32 Ohio Misc. 81, 285 N.E.2d 768 (C.P. 1972) and Dollar Sav. \& Trust Co. v. Kirkham, 21 Ohio Misc. 163, 255 N.E.2d 892 (C.P. 1969).

35. First Nat'l Bank v. Ettlinger, 465 F.2d 343 (7th Cir. 1972); Beals v. State St. Bank \& Trust Co., 367 Mass. 318, 326 N.E.2d 896 (1975); Bank of N.Y. v. Black, 26 N.J. 276, 139 A.2d 393 (1958); In re Deane's Will, 4 N.Y.2d 326, 151 N.E.2d 184, 175 N.Y.S.2d 21 (1958); In re Estate of Huntington, 9 Misc. 1012, 170 N.Y.S.2d 452 (Sur. Ct. 1957); 5 A. Scotr, LAW OF Trusts § 642, at 4061-65 (3d ed. 1967); Durand \& Herterich, Conflict of Laws and the Exercise of Powers of Appointment, 42 CORNELL L.Q. 185, 190 (1957).

36. See, e.g., In re Deane's Will, 4 N.Y. 2d 326, 151 N.E.2d 184, 175 N.Y.S.2d 21 (1958).

37. See In re Bauer, 14 N.Y.2d 272, 200 N.E.2d 207, 251 N.Y.S.2d 23 (1964); RESTATEMENT 
alleviate this problem, courts lave not yet applied it in the powers of appointment area, ${ }^{38}$ and it still might result in applying the law of some state other than that anticipated by the drafter of the donee's will. ${ }^{39}$ The combination of cloice of law rules and rules excluding extrinsic evidence $^{40}$ las often produced results that are clearly contrary to the intent of the donee. ${ }^{41}$

\section{Development of The Doctrine of Exercise by IMPLICATION: $1599-1830$}

In Sir Edward Clere's Case, ${ }^{42}$ decided in 1599, the English courts first considered whether a power of appointment could be exercised by a will that did not refer to the power. In that case, the owner of a tract of land made a feoffment to the use of such persons as he should appoint by his will. ${ }^{43}$ His will devised the real estate subject to the power but did not mention the power. Although he owned the land subject to the power, he was not able to devise it directly because of the limitations imposed by the Statute of Wills. ${ }^{44}$ The description of the property contained in the will, lowever, unequivocally referred to the appomtive real estate, and the court held that the devise in his will must have exercised the power: "[O]therwise the devise shall be utterly void." 4

(SECOND) OF CoNflict of Laws $§ 6$ (1971); 65 Colum. L. Rev. 348 (1965).

38. See cases cited note 35 supra.

39. The state whose law governs interpretation of the donee's will might not have the dominant interest in the devolution of the appointive assets. Even the drafter conscious of the problem might not anticipate correctly the weight to be assigned to factors such as the situs of the trust and the domicile of the donor and the takers in default. See, e.g., Bank of N.Y. v. Black, 26 N.J. 276, 292, 139 A.2d 393, 401-02 (1958); In re Deane's Will, 4 N.Y.2d 326, 331, 151 N.E.2d 184, 186, 175 N.Y.S.2d 21, 23-24 (1958). See Annot., 15 A.L.R.3d 346 (1967), and Annot., 16 A.L.R.3d 911 (1967), for collections of cases litigating the question whether a power has been exercised by a general disposition or residuary clause.

40. This would also apply to a lesser extent to those rules excluding testators' declarations, particularly instructions to the drafter of the will.

41. See, e.g., In re Deane's Will, 4 N.Y.2d 326, 151 N.E.2d 184, 175 N.Y.S.2d 21 (1958). See text accompanying notes $136-44$ infra.

42. 77 Eng. Rep. 279 (K.B. 1599). This case also established the validity of the power appendant, a power of the owner in fee simple to appoint a fee simple, which could exist separately from the ownership itself. The case illustrates the utility of the device. See id. at 280 n.(B).

43. This device was used to provide landowners with a means of controlling the devolution of their property by will when lands were not otherwise devisable. $7 \mathrm{~W}$. HOLDSwORTH, A HISTORY OF ENGLiSH LAW 150-5I (1926); 4 W. HOLDSWORTH, A History OF ENGlish LAW 474-75 (1924); T. Plucknett, A Concise History of the Common law 580-82 (5th ed. 1956).

44. The Statute of Wills, 32 Hen. 8, c. 1 (1540), conferred complete powers to devise over socage lands and over two-thirds of land held by knight-service. PLUCKNETT, supra note 43, at 587.

45. 77 Eng. Rep. at 280. In Clere's Case, Clement Harwood was seized of three acres of land, each of equal value, held in capite. He made a feoffment of two acres im fee to the use of his wife 
The holding in Clere's Case was confirmed by Lord Hardwicke in $1739,{ }^{46}$ and throughout the following century, the English Court of Chancery developed and refined the principle that a disposition of property subject to a power could sufficiently manifest imtent to exercise the power.

The first question to arise was whether a general disposition of property similar to the appoimtive property sufficiently manifested an intent to exercise. In Molton $v$. Hutchinson, ${ }^{47}$ also decided in 1739 , the court held that a residuary bequest of personal property would not exercise a power over $£ 400$ of South Sea stock. ${ }^{48}$ The report of the case does not state whether the donee owned any personal property that passed under the residuary bequest. Five years later, in Ex parte Caswall, ${ }^{49}$ the court held that a general devise of "my effects, real and personal, of what nature kind or quality so ever"s0 did not exercise a power over real estate. The donee in that case did own other real estate that passed under this devise. ${ }^{51}$ In 1752 the court extended the princi-

for her jointure. He later made a feoffiment by deed of the third acre to the use of such persons as he should appoint by his will. His will devised the third acre to the plaintiffs predecessor in interest. Id. at 279. The court held that the third acre passed under the will as an execution of the power because his ability to devise was exhausted by the feoffment of the two acres to the use of his wife. Since he could not make a devise, "the devise ought of necessity to enure as a limitation of an use, or otherwise the devise sliall be utterly void." Id. at 280 (footnote omitted).

46. In Probert v. Morgan, 26 Eng. Rep. 281 (Cl. 1739), Lord Hardwicke stated:

If a man has a power to charge an estate, it is not necessary, in the execution of it, he should refer to the deed out of which the power arises; for in a court of equity it is enough that his intent appears, and if in the execution he sufficiently describes the estates he had a power to charge, the estate is certainly bound ... .

Id. (emphasis in origimal). Simce Probert, it has been settled that the donee's bequest or devise of the property subject to the power is a sufficient manifestation of intent to exercise the power. See SUGDEN 337-38.

47. 26 Eng. Rep. 351 (M.R. 1739).

48. Id. The report states:

Parol evidence was offered to prove it was the intent of Freeman Cutler, that the $\mathfrak{1 0 0}$ should be disposed of by his will, but was not allowed.

The Master of the Rolls, though he acknowledged a man might execute a power or [sic] appointment, without particularly reciting it, yet here he lield this was not an execuId. tion of the power, but the $£ 400$ must go over according to the will of the first testator.

49. 26 Eng. Rep. 351 (M.R. 1744). George Caswall, Sr., surrendered copyhold estate to the use of his wife for life, then to his children, for life, then in trust to such uses as he should appoint, in default of appoimtment to his son John. His will gave the residue of his estate to his other son George. Son John had died a bankrupt a year before the testator's will was executed. Son George petitioned to remove the appointive property from bankruptcy on the ground that the will made a good appointment to him. His petition was denied.

50. Id.

51. The court said:

Though a man may execute a power without reciting, or taking the least notice of the power, yet it is necessary he should mention the estate which he disposes of, and must do such an act as shews he takes notice of the thing which he had a power to dispose of. 
ple of Clere's Case: in Wallop v. Earl of Portsmouth, ${ }^{52}$ the court held that if the donee owned no real estate that could pass by a general devise, the devise would exercise a power over real estate, even though the property was not specifically described.

In Molton, Caswall, and Wallop, the donee's will gave no clue as to whether the donee intended to exercise the power. Unlike Clere's Case, in which it was apparent that the donee intended to transfer ownership of the appointive property by his will, these cases required the court to go beyond the language of the will to find an intent to exercise the power. The willingness of the court to consult extrinsic evidence and the inferences it was willing to draw from such evidence were crucial factors in deciding these cases.

During the period from 1599 to 1830 , the rules on admissibility of extrinsic evidence to aid in the interpretation of written documents were coinpletely transformed. ${ }^{53}$ In 1591 , Lord Coke stated the basic rule as follows:

The constructions of wills ought to be collected from the words of the will in writing, and not by any averment [that is, circumstances] of evidence out of it; for it would be full of great inconvenience, that none should know by the written words of a will, what construction to make, or advice to give . . . [if] it should be controlled by collateral averments out of the will. ${ }^{54}$

The only exception then recognized to the rule of general exclusion of extrinsic evidence was in the case of an equivocation, or "latent ambiguity," to use Lord Bacon's term..$^{55}$ By 1831 the rules had changed to satisfied.

Sir George Caswall had other lands on which the devise to George Caswall might be Id. at 352 .

52. Rolls, Apr. 25, 1752, reprinted in SugDEN app., at 916, discussed in id. 318 . The court stated:

[T]hat though she does not refer to the power, nor describes the particular lands subject to it, otherwise than by the words $m y$ estate, yet if she had no real estate (as from its being stated that all her estates were settled, I presume she had not), I think the will as Id. 917. penned, must from necessity be understood to mean the estates mcluded in her power.

53. See THAYER, supra note 23 , at 390-483; 9 Wigmore $\$ 2470$.

54. Lord Cheyney's Case, 77 Eng. Rep. 158, 158 (Wards 1591). Wigmore describes the conceptual basis of Coke's statement:

It was a part of the stiff formalism of earlier imterpretation, not only that the law should fix the meaning of words and phrases . . . but also that all aids to the meaning must be found in the document itself. It is the document that "speaks," and if the document does not speak for itself, we cannot make other things speak instead of it,-such was the notion. The purely relative nature of words-their necessary association with external objects-was as yet not conceived. They were tangible tools, which must do their own work or remain imeffective. The writing fixed the will of the writer, and to look away from the writing was suggestive only of deviation and uncertainty.

9 WIGMORE $\S 2470$, at 224-25.

55. An equivocation occurs when the description used in the will can apply to more than one taker or piece of property and it is apparent that only one of the possibilities was intended by the 
the point that all relevant extrinsic facts, except direct declarations of the testator's intent, were admissible. ${ }^{56}$ In the case of an equivocation, even the testator's direct declarations of intent were admissible. ${ }^{57}$

This liberalization of the rule against extrinsic evidence did not take place witlout a struggle, and the cases involving powers of appointinent reflect the uncertainty of the courts in dealing with the evidentiary issues. Even under the strictest view, lowever, some extrinsic evidence must always have been used to tie the words of the will to the property and takers they described. In the early powers cases, extrinsic evidence was obviously used to determine that the donee held a power of appointment and that the description of the property used in the will would fit the property subject to the power. In addition, extrinsic evidence was used in Caswall and Wallop to determine whether the donee owned other real property that would pass by the devise. ${ }^{58}$ In Molton $v$. Hutchinson, ${ }^{59}$ however, the court rejected an offer to prove by parole evidence that the donee imtended the appointive property to go to his residuary legatees rather than to the takers in default. The report does not state what sort of evidence was offered, but presumably it consisted of statements by the donee rather than of circumstances from which an

testator. 9 WIGMORE $\S 2472$, at 233. Bacon seems to have invented the phrases ambiguitas latens and ambiguitas patens, which appeared in his Maxims. THAYER, supra note 23, at 423; WIGMORE $\S 2472$, at 239 . Thayer makes it clear that his latent ambiguity is the same as an equivocation:

Quite in the way of the conceptions of that time, he says that an anbiguity which appears in the writing itself can only be cured by the writing itself; i.e., by merely construing the writing, or, in some cases,-as where one who has a hundred acres gives ten acres,- - by allowing to the donee the choice. He puts the case of giving land to I.D. and I.S. et haeredibus, without saying whose heirs, . . . and adds that this sort of thing "cannot be holpen by averment," "for that were to inake all deeds hollow and subject to averments, and so, in effect, that to pass without deed which the law appointeth shall not pass but by deed." [This is a patent ambiguity because haeredibus can apply only to one of the takers, not to both.] ... With this sort of obvious and imcurable ambiguity, he contrasts the latent and curable kind, such as had been discriminated in Cheyney's case; namely, the old instance of two things or persons of the same name. There, he says, since the writing is clear upon its face, and the ambiguity only appears extrinsically, you inay remedy it extrinsically, and even by averring the actual mtention of the writer, since the form of the writing really does describe the thing or person intended.

THAYER, supra note 23, at 423-24 (footnote omitted); see 9 WIGMORE § 2473, at 239.

56. THAYER, supra note 23, at 445 . This is, of course, still the rule today. 9 WIGMORE $\$ 2470$, at 227-28. Wigmore traces its survival froin the old formahisin in the rule against disturbing a plain meaning, and he rejects the rule as unsound, stating that "the plain meaning is simply the meaning of people who did not write the document." Id. $\$ 2462$, at 191. He suggests observing Lord Justice Bowen's opinion that this should be "not so much a canon of construction as a counsel of caution." Id. $\S 2462$, at 193 (quoting In re Jodrell, 44 Ch. D. 590, 614 (1890))

(Bowen's language actually reads, "not so inuch as a canon of construction . . .").

57. 9 WIGMORE $\$ \S 2472-2473$.

58. See notes 49, 51, \& 52 supra. Froin the report in Caswall, it does not appear that the will recited the ownership of other lands by the testator. Nor does it appear in Wallop that the will recited the testator owned no lands.

59. 26 Eng. Rep. 351 (M.R. 1739). 
inference of intent to exercise could be drawn. ${ }^{60}$

In Andrews v. Emmot, ${ }^{61}$ decided in 1788 , the court combined the rule against extrinsic evidence with a strict standard on the quantum of evidence required to support an inference of intent to exercise. The case involved two powers over a wife's personal property. This property had been transferred to the trustees of her marriage settlement. In the event that there were no children of the marriage, the husband had a power to appoint the remainder interest in the fund. In default of his appointment, the wife had a power to appoint, and in default of her appointment, the remainder was to be transferred to her executors or administrators. The husband's will, made shortly after the marriage, did not inention the power, but after several specific bequests and legacies gave the residue of his estate to John Emmot. There were no children of the marriage, and the husband predeceased the wife. The wife and John Emmot each claimed the appointive fund. ${ }^{62}$ The wife claimed the appointive fund after exercismg her power in her own favor. The basis of Emmot's claim was that without the appointive assets there would be nothing left to pass to him under the residuary clause after payment of debts and legacies. ${ }^{63}$

Sir Lloyd Kenyon, the Master of the Rolls, rendered what even then inust have seemed a conservative opinion, holding that the husband's will did not execute the power and that the evidence of his personal property at the time he executed the will must be excluded. The reasoning he gave echoes that of Lord Coke, that such evidence "inight lead to conjecture, which is a method of deciding cases to be avoided, if possible." ${ }^{4}$ In affirming, Lord Thurlow articulated a standard for determining when an inference of intent to exercise was proper:

It is too late now to expect that a testator, in order to execute a power, shall make an express reference to it; because it has been de-

60. The report states that "[p]arol evidence was offered to prove it was the intent of Freeman Cutler, that the $£ 400$ should be disposed of by his will, but was not allowed." Id. at 351 .

61. 29 Eng. Rep. 162 (Ch. 1788).

62. Id. at 165 .

63. His estate was short $f 664,1 s .5 d$. to pay legacies and debts without the appointive fund. Kenyon refused to refer the case to a master, stating that "the testator has not referred to the power, but has done the act generally; and he had property of which he could dispose. To send it to an enquiry as to the quantuin of that property, might lead to conjecture . . ." Id. at 164 . Apparently, what Kenyon meant here is that it inight be difficult to determine whether there was or was not enough property on which the will could operate when executed to permit an inference of intent to exercise. Wallop and Caswall had of course drawn the line at any property: if the donee owned any real estate on which the devise could operate, no intent to exercise the power would be inferred. Kenyon does not appear to have considered this possibility, perhaps because it would be an unusual testator who had no personal property.

64. Id. Wigmore refers to Kenyon and Eldon as "reactionaries and mainstays of conservatism." 9 WIGMORE $§ 2461$, at 189. 
termined that, if a man disposes of that over which he has a power, in such a inanner that it is impossible to impute to him any other intention but that of executing the power, the act done shall be an execution of the power. ${ }^{65}$

This strict standard on the quantum of evidence, in conjunction with the exclusionary rule, played a substantial role im determining or justifying the results of later cases, particularly those in which the donee's imtent was most flagrantly frustrated.

On the facts of the case, however, the result in Andrews is quite reasonable. Because extrinsic evidence showed that the fund belonged to the wife originally and that the husband's will was executed early in their marriage when he could not have known or expected that there would be no children of the inarriage, ${ }^{66}$ the result seeins fair. There is no indication that the donee intended to exercise the power. ${ }^{67}$

So far as can be judged from the reports, ${ }^{68}$ the fairness of the result in Andrews is typical of the cases decided before 1800. There are no cases in which the court clearly frustrated the donee's intent. ${ }^{69}$ The

65. 29 Eng. Rep. at 165 (emphasis added). The exclusionary rule applied only to personal property: under Caswall, see notes 49 \& 51 supra, and Wallop, see note 52 supra, extrinsic evidence was clearly admissible when it related to real property owned by the testator. Since the rule of Wallop depended on the testator's owning no real property on which the devise could operate, evidence as to such ownerslip had to be admitted. At the time these cases were decided, of course, wills of real estate were not ambulatory, so real estate owned at death would have been irrelevant. See note 90 infra. See also T. ATKInson, Wills $\S 3$, at 18 (2d ed. 1953).

66. The information on the date of execution of the husband's will appears only in the report of the arguments. See 29 Eng. Rep. at 163 . Although the will may have been dated, it seems unlikely that it also showed the date of the marriage.

67. Although it would have seemed reasonable to insist that when, as in this case, the donor holds a reversionary interest that would be divested by exercise of the power, the donee's intent to exercise be very clearly manifested, the decision was not based on this ground. Thurlow justified the decision as follows:

But the doctrine [exercise of powers by implication] is not carried, by any case, further than this, and it would be cruel to do it; as it would be throwing the property of testators into utter confusion. Then you must not go out of the instrument itself, to gather the construction of it. I do not mean by sayimg this to exclude the rule, that where there is what has been called a latent ambiguity in the will you shall not go out of the will to explain the testator's intention by circuinstances; but to enquire into the testator's situation, in order, from thence, to gather what it is probable he meant is a great deal beyond that.

Id. at 166 (emphasis in original).

68. The reports from this period are not always very complete, and, of course, it may be that evidence indicating an intent contrary to the result was not mentioned. From what we can tell, however, there were no cases in which the result was to defeat the testator's intent. Since the reports in the next period make it very clear when the imtent is being frustrated, it seems reasonable to assume that the reports would have mentioned the problem had it been common.

69. Several more cases were decided before 1800 , all by Lord Lougliborough or Sir Richard Pepper Arden, later Lord Alvanley, Master of the Rolls. Hales v. Margerum, 30 Eng. Rep. 1021 (M.R. 1796), involved a power given to a daughter over funds held in trust for her sole use and benefit, to be kept free of her husband's control. She was given a general testamentary power over the remainder, and in default the property was to go to her daughter. Sir R.P. Arden held that the 
character of the cases changed dramatically, however, immediately after Lord Eldon became Chancellor in $1801 .^{70}$ His first decision on im-

daughter's will exercised the power even though it did not refer to the power because "[t]his is not a mere power to dispose, but an absolute gift, qualified only as to her situation as a married woman .... [S]he does mean to include this sum. It inust be included under the word 'my . . . ." Id. at 1022. The result follows, of course, if one accepts his characterization of the gift. This is a little difficult, howevcr, in light of the gift in default.

Another decision of Sir Arden, Langhain v. Nenny, 30 Eng. Rep. 1109 (M.R. 1797), involved a marriage settlement of the wife's property, like Andrews v. Emmot, 29 Eng. Rep. 162 (Ch. 1788). The husband, who was given a power over the remainder, left a will that made sinall legacies and appointed executors. It was held that his will did not exercise the power. 30 Eng. Rep. at 1110-11. The opinion contains a curious statement in which Arden criticizes the cases: "I rather wish, the Court liad taken another line in these cases; and had held, that any general words be sufficient to execute such powers: but I am not at liberty to say so." Id. at 1111 . The statement is curious because holding the power to have been exercised here would nost likely have defeated the husband's intent. SUGDEN 314.

Arden also decided Croft v. Slee, 31 Eng. Rep. 32 (Ch. 1798), in which he held that a will did not exercise a power even though the testator's estate was alleged to be short to pay the debts and legacies. It did not appear that the testator really intended to exercise the power.

See 12 W. Holdsworth, A History of ENGLISH LAw 328-29 (1938) for the circumstances of Arden's appointment.

Loughborough decided Standen v. Standen, 30 Eng. Rep. 791 (Ch. 1795). It was affirmed on appeal to the House of Lords. 2 Eng. Rep. 1021 (H.L. 1797). Under the husband's will the wife took an interest for life in his real and personal estate, with power to appoint one-half thereof by her will. There was a gift in default. The wife's will specifically bequeathed a few items of tangible personalty, identified in her will as her husband's, and then devised the residue of her estate, both real and personal. She owned no real estate. Although the will could have been held to exercise just the power as to the realty on the authority of Clere's Case and Wallop, Lord Loughborough held that the will exercised the power as to the personal estate as well as the real estate and placed the holding on broader ground:

It is a little hard to attempt to explain, that it was not her estate. How could she have

had it more than by the enjoyment during life and the power of disposing to whatever

person and in whatever manner she pleased with the small addition of two witnesses. By

her will she gave all her estate and effects. . . . It is hard to say, that using that expres-

sion she meant to distinguish, and not to include, this; which is as absolutely her's [sic] as

any other part of her property. . . .

30 Eng. Rep. at 793 . The idea that a person who has both a life estate and a general testamentary power should be regarded as the owner of the property, so that appointive property should pass by any general disposition of the donee's property, was not followed by the later Enghish cases. However, it was pickcd up by the law reformers in the next century, and it may have laid the theoretical base on which their statutes were constructed. See notes 113-27 infra and accompanying text.

See 13 W. HOLdSWORTH, A History OF ENGLISH LAw 578-80 (1952), for a discussion of Loughborough's career as Lord Chancellor.

70. He held this position with only one interruption until 1827. See $13 \mathrm{~W}$. HoLDSWORTH, supra note 69, at 578 n.3. The Chancellors, Masters of the Rolls, and Vice-Chancellors during the periods we are considering were as follows:

\section{Chancellors}

Hardwicke, 1737-1756

Thurlow, 1778-1792

\section{Masters of the Rolls Vice-Chancellors}

Verney, 1738-1741

Fortescue, 1741-1749

Strange, 1750-1754

Clarke, 1754-1764

Sewell, 1764-1784

Kenyon, 1784-1788 
plied exercise of powers, rendered in Nannock v. Horton, ${ }^{71}$ strictly applied the standard set out in Andrews v. Emmot, ${ }^{72}$ setting a tone and direction that triggered legislative intervention in the 1830s.

In Nannock v. Horton, ${ }^{73}$ the donee held a general power, given to him by lis father, to appoint $£ 4000$ of three-percent Consolidated Bank Annuities by deed or will. The donee's will did not mention the power but gave $£ 2000$ of three-percent Consolidated Bank Annuities to a friend, $£ 1000$ to his wife, and $£ 500$ eacls to five other legatees. Aside from the fund of $£ 4000$ consols subject to the power, the donee's estate was insufficient to pay the legacies, and he owned no such consols in his own riglit. ${ }^{74}$

Lord Eldon held that the disposition of $£ 2000$ of three-percent Consolidated Bank Annuities was not such a specific description of property subject to the power ( $\$ 4000$ of three-percent Consolidated Bank Annuities) that it was impossible to impute to tlie donee any other intention but that of exercising the power. ${ }^{75} \mathrm{He}$ reasoned that if the testator had sufficient assets and owned no three-percent consols at death, this bequest in the will would serve to direct the executors to purchase sucli consols for the legatee. Thus, it was possible that the donee did not intend to exercise tlie power. Eldon concluded, "it is very difficult to say that what would anount to that direction [to the executors to purchase such consols] in a will, is to be construed into a gift of that which was not his to give, but over whicl he had a power."76 Havimg announced this rule, whicl is certainly a strict application if

\author{
Loughborough, 1793-1801 \\ Eldon, 1801-1806 \\ Erskine, 1806-1807 \\ Eldon, 1807-1827 \\ Lyndhurst, 1827-1830 \\ Brougham, 1830-1834
}

Arden, 1788-1801

Grant, 1801-1818

Plumer, 1818-1824

Gifford, 1824-1826

Lyndhurst, 1826-1827 Shadwell, 1827-1850

Leach, 1827-1834

\author{
Plumer, 1813-1818 \\ Leach, 1818-1827 \\ Hart, 1827
}

Id; 12 W. HolDSWORTH, supra note 69, at 245, 297 n.l.

71. 32 Eng. Rep. 158 (Ch. 1802).

72. 29 Eng. Rep. 162 (Ch. 1788).

73. 32 Eng. Rep. 158 (Ch. 1802).

74. Id. at 160 .

75. This, of course, is the standard articulated in Andrews. See text accompanying note 65 supra. Eldon says:

In this will there is nothing, that refers to the power, nothing necessarily descriptive of the property over which it existed; and therefore, whatever might have been the intention, I am bound by the authorities to say, this testator did not mean to affect any property but what was his own.

32 Eng. Rep. at 162.

76. 32 Eng. Rep, at 161 . 
not a departure from Andrews v. Emmot ${ }^{77}$ Eldon made the remarkable statement: "I am not sure, the rule does not oblige the Court to act against what probably might have been the intention nine times in ten."78 Subsequent decisions followed the rule in Nannock: even an exact description of the property subject to the power would not suffice to indicate intent to execute if the description could refer to other property that could be acquired by the donee's executors. ${ }^{79}$

In Nannock Lord Eldon also affirmed and articulated a new basis for the ruling im Andrews v. Emmot ${ }^{80}$ that prevented examination of the amount of the testator's property at the time the will was executed for evidence of his intent. ${ }^{81}$ Eldon reasoned that the words "my estate" or "my property" could not reasonably refer to property that the testator did not own but over which he had only a power. ${ }^{82}$ Thus, the language was not ambiguous, and there was no occasion for the court to admit extrinsic evidence as to the state of the donee's assets. Any general description of property preceded by the pronoun "my" could not be a description of appoimtive property. This rule would apply to all descriptions of personal property except when the description could refer only to the appointive assets. In such a case, the description would be ambiguous, and extrinsic evidence would be admissible to show intent. $^{83}$

Eldon's two holdings evolved into the rule that no disposition of personal property - except by specific bequest-could exercise a power of appointment even when the donee had no personal property other

77. 29 Eng. Rep. at 165.

78. 32 Eng. Rep. at 161 .

79. See, e.g., Webb v. Honnor, 37 Eng. Rep. 410 (M.R. 1820); Bennett v. Aburrow, 32 Eng. Rep. 492 (Ch. 1803).

80. 29 Eng. Rep. 162 (Ch. 1788).

81. The case of Andrews $v$. Emmot and the others of that class are clear, and distinct, and positive, and express, to the point, that you are not to inquire into the circumstances of the testator's property at the date of the will, to determine, whether he was executing the power or not.

32 Eng. Rep. at 162.

82. [T] hat, where it is sufficiently described, the gift shall hold as an interest or as a power. But the subject must be described in apt terms. The difficulty I had as to Andrews v. Emmot was, how the Court could by any evidence, that could be stated by the Report, have brought under the words "iny personal estate," that property which was in no sense Id. his.

83. Thus, if the testator makes a bequest of "iny gold watch" and a "piano-forte" and the testator owns no such items and has never owned such items, the description is anbiguous, and extrinsic evidence is admissible to show not only this fact, but also the fact that the testator did have a power to dispose of such items, and that the dispositive language used is sufficiently clear to exercise the power. Hughes v. Turner, 40 Eng. Rep. 254 (Ch. 1835). See also Walker v. Mackie, 38 Eng. Rep. 733 (M.R. 1835); Lownds v. Lownds, 148 Eng. Rep. 745 (Ex. 1827); Jones v. Curry, 36 Eng. Rep. 300 (M.R. 1818); SUGdEN 320. 
than the appointive assets. ${ }^{84}$ The rule excluding extrinsic evidence, particularly of the donee's assets, made proof of intent to exercise impossible. The court's position led to frustration of the donee's clear intent in several cases. ${ }^{85}$ Two of the most egregious were Jones $v$. Tuck$e r^{86}$ and Jones v. Curry. ${ }^{87}$

In Jones v. Tucker, ${ }^{88}$ the donee had no personal property except her furniture. In addition, she had a power to appoimt $£ 100$. Her will bequeathed her furniture and $£ 100$ to Jones, but did not mention the power. Sir William Grant, Master of the Rolls, held that there was no execution of the power, even though in his "own private opinion" he thought she did intend to exercise it. ${ }^{89}$ His reasoning was essentially that since a will of personal property transfers what the testator owns at death, the assets owned at the time the will was executed cannot be conclusive on the question of the donee's intent. ${ }^{90}$ Here, for example, the donee inight have contemplated acquiring $£ 100$ after she made the will, and those funds could then satisfy the legacy. This is another application of the "inipossible to impute. . . any other intention but that of executing the power" standard of Andrews v. Emmot. ${ }^{91}$

In Jones v. Curry, ${ }^{92}$ the donee's entire estate, aside from the assets subject to the power, consisted of three sets of window curtams. The donee's will contained specific bequests of several items of tangible personal property subject to the power as well as a general disposition.

84. See Jones v. Curry, 36 Eng. Rep. 300 (M.R. 1818).

85. See, e.g., Hughes v. Turner, 40 Eng. Rep. 254 (Ch. 1835); Webb v. Honnor, 37 Eng. Rep.

410 (M.R. 1820); Lowes v. Hackward, 34 Eng. Rep. 281 (Ch. 1811).

86. 35 Eng. Rep. 1044 (M.R. 1817) (decided by Sir William Grant).

87. 36 Eng. Rep. 300 (M.R. 1818) (decided by Sir Thomas Plumer, M.R.).

88. 35 Eng. Rep. 1044 (M.R. 1817).

89. In my own private opinion, I think the intention was to give the $£ 100 \ldots$ but I do not conceive that I could judicially declare the power to have been executed, even if the result of an inquiry should verify the representation that is made as to the state of her property.

Id. at 1046.

90. The Statute of Frauds, 29 Car. 2, c. 3, $\$ 6$ (1677), estabhished that wills were ambulatory as to personalty. E. Scoles \& E. Halbach, Problems \& Materials on Decedents' Estates \& TRUSTs 4-5 (2d ed. 1973).

91. 29 Eng. Rep. at 165. Sir Williain Grant said:

If a person, having no property at all, and only a power over a certain sum of money, gives that single sum, little doubt can arise as to the intention. But the question is, how we can get at the fact, and whether there can be an inquiry for the purpose of ascertaining it. . . Some property, however, she had. . . . [W] hat is to be the quantum of property that shall furnish the criterion for deciding whether a testator, naking a bequest, is or is not exercising a power? It is not like an inquiry whether there be any thing but copyhold to answer a devise of land. The question there is, whether there was any thing for the will to operate upon at the time when it was made? A will of personalty speaks at the death. The state of that description of property at the time of the will, does not furnish the same evidence as to the intention.

35 Eng. Rep. at 1045-46.

92. 36 Eng. Rep. 300 (M.R. 1818). 
Despite a "conviction" that the donee intended to execute as to all the appointive property, the court held that there was no exercise as to any assets other than those specifically bequeathed. ${ }^{93}$ The court explained the result: "The distinction ... [ [having been] established between property and power, these words ["1ny estate and effects"] . . . are not sufficient to designate with due certainty, property not her own, but of which she was empowered to dispose."94 In both Tucker and Curry the court considered itself bound by the precedents, as interpreted in $\mathrm{Nan}$ nock. The court thus reached results that clearly frustrated the donee's intent.

The distinction between power and property as used in the Tucker and Curry decisions is important because it was later picked up by courts and law reformers who seem to have misunderstood its significance. Because the reformers apparently thought that the questionable results in these cases had been caused by treating property over which testators had powers of appointment differently from property that they owned, they fashioned reforms that treated the two as identical. ${ }^{95}$ This einphasis on similar treatment of power and property prevented the reformers from focusing on the exclusion of extrimsic evidence as the principal cause of the frustration of the donee's intent in these cases.

Prior to the Wills Act of $1837,,^{96}$ devises of real estate were always specific and could not pass real property acquired after the execution of the will. Thus, even after the courts had excluded extrimsic evidence as to the donee's personal property, ${ }^{97}$ they still permitted such evidence as to his real property owned at the time of execution. Because a devise of land could not operate as a direction to the executors to purchase and because it could not conteinplate a later acquisition of land to satisfy the devise, courts continued to hold that if the testator owned no land on which the language of devise could operate, it would exercise the

93. Id. at 303 .

94. Id. Plumer also said:

[I]t is now clear that the Court cannot look beyond the will. Whatever is the inadequacy of a testator's property to satisfy the terms of the will, and whatever nay be the conviction of the Court of his imtention to execute the power, the state of his personalty, at the time of the will or of the death, cannot be examined for the purpose of collecting evidence of his intention.

Id. at 302. He added that if this will had had an unequivocal devise of real property, it would have executed the power as to the real property. The language "my estate and effects," however, would operate on personalty, so that there was no necessary execution of the power over the realty. Id. at 303.

95. See text accompanying notes 104-14 infra. Parts of the statutes are set forth in text accompanying notes 106 \& 110 infra.

96. 7 Will. 4 \& 1 Vict., c. 26.

97. See, e.g., Nannock v. Horton, 32 Eng. Rep. 158 (Ch. 1802); Andrews v. Emmot, 29 Eng. Rep. 162 (Ch. 1788). 
power. ${ }^{98}$

Even this rule, however, was apphed to produce absurd results. In Napier $\nu$. Napier, ${ }^{99}$ decided in 1826, the donee held a power to appoint lands located in several parishes, including Lamyat. He also owned outright some lands in Lamyat Parish and in five other parishes where there was no appointive property. His will did not refer to the power and devised to his son all "iny" real estate situated in nine named parishes, mcluding Lanyat. The court held that, although the devise would exercise the power over property in the three parishes where he owned no land, it could not pass the appointive property in Lamyat Parish, because the testator had owned property there that could give effect to the devise. ${ }^{100}$ The result was an execution of the power as to all lands except those in Lamyat Parish. This absurd result was not unique, ${ }^{101}$ and it illustrates how far the courts, under Lord Eldon's gui-

98. See, e.g., Wallop v. Earl of Portsmouth, Rolls, Apr. 25, 1752, reprinted in SugDEN app., at 916; $c f$. Lewis v. Lewellyn, 37 Eng. Rep. 1034 (Ch. 1823) (power was exercised as to copyhold but not as to freehold estates); Hurst v. Earl of Winchelsea, 96 Eng. Rep. 1238 (K.B. 1759) (doctrine of worthier title applied so that appointee, who was donee's heir, took by descent rather than by purchase).

99. 57 Eng. Rep. 489 (V.C. 1826).

100. The testator devised lands in nine named parishes to his son. In five of the parishes named he owned lands in fee only, in three he owned no lands but had powers over lands, and in one he both owned land outright and had a power over other lands. It was admitted that the lands in the three parishes where he had only appointive property passed under the devise of "iny manors, messuages, lands, tenements and hereditaments . . . "Id. at 490, 492. The court rehed on Lewis v. Lewellyn, 37 Eng. Rep. 1034 (M.R. 1823), for the point that exercise of the power as to part of the property subject to it would not exercise the power as to the balance. In that case the disposition was of all the testator's freehold and copyhold estates. The testator had a power over both freehold and copyhold estates, and he also owned freehold estates. He owned no copyhold estates. Sugden, Lewellyn's attorney, argued for the taker in default that if the words used in the testator's will operated to exercise the power over the copyhold lands, they inust also execute the power over the freehold. Further, the reason for the rule on real property did not extend to devises of copyhold because they were ambulatory. $I d$. at 1035 . The court nevertheless held that the will exercised the power as to the copyhold only: "[A]ll the words of a will should, if possible, have effect, and these words with respect to copyholds cannot be satisfied by any thing short of considering them an execution of the power. ..."Id. Vice-Chancellor Leach in Napier, after finding that the decision in Lewis controlled, said:

[I] it were unprejudiced by decision, it would present very great difficulty. But the very

point occurred in Lewis v. Lewellyn . . . . In cases of this nature, I think it for the advan-

tage of the public to abide by decision, until that decision is corrected by the Court of

Ultimate Resort.

57 Eng. Rep. at 492.

101. See Doe v. Roake, 130 Eng. Rep. 398 (C.P. 1825), rev'd sub nom. Denn v. Roake, 108 Eng. Rep. 268 (K.B. 1820), affd, 5 Eng. Rep. 1, 6 Eng. Rep. 589 (H.L. 1830). In that case, the donee owned an undivided one-lialf of the property in fee and held a general power over the other half. Her will devised all her freehold estates to Roake for life, on condition that he unake repairs, with remainder over.

In the Court of Common Pleas, Judge Best recognized Thurlow's articulation of the applicable standard froin Andrews and concluded: "We think it impossible to impute any other intention to Mrs. Trymmer than that of executing the power she had reserved to herself in the estate in 
dance, had strayed from attemptimg any reasonable search for the donee's intent by the 1830 s.

To summarize, the history of the Enghish cases on exercise of powers begims with the court stretching to carry out the apparent intent of the testator in Sir Edward Clere's Case, ${ }^{102}$ even though he had not used the proper form, and ends in the 1820s with the court obstmately applying mechamical rules excluding extrinsic evidence of the donee's intent and frustratimg that intent as often as nine times out of ten. ${ }^{103}$ The holdings in the later cases are clearly a result of the rules excluding extrinsic evidence and of the requirements regarding the quahty of evi-

question . . . ." 130 Eng. Rep. at 404. Despite the argument that it made no sense to require repairs of a tenant of only an undivided one-half interest, the King's Bench reversed. Chief Judge Abbott stated the controlling principle to be that " "ii]f an Act will work two ways, the one by an interest, the other by an authority or power, and the Act be indifferent, the law will attribute it to the interest, and not to the authority . . . "’ 108 Eng. Rep. at 271 (quoting The Commendam Case, 80 Eng. Rep. 290, 308 (K.B. 1623) (opinion of Hobart, C.J.)). Abbott then added that it appeared probable that the donee had forgotten that she held only a power over half of the estate, but he concluded:

Although, therefore, we may think the testatrix intended that the entirety should go in strict settlement on the family of her sister, yet we think it is possible to suppose that the testatrix had no intention to execute the power. And if the intention to execute the power be doubtful, the will cannot in our opinion be deemed to be an execution of it.

108 Eng. Rep. at 273.

The House of Lords affirmed Chief Judge Abbott's decision. Lord Wynford observed that he believed that 999 out of 1,000 would say that she did intend to execute the power, but that the result was in accord with the rules. 5 Eng. Rep. at 8, 6 Eng. Rep. at 594. He stated: "I agree with the Lord Chief Baron, that, unfortunately, we are confined by the rules which have been laid down. Rules, with respect to evidence of intention, are bad rules, and I trust I shall live to see them no longer binding on the Judges." 5 Eng. Rep. at 8; see 6 Eng. Rep. at 594. Lord Tenterden opined that it was better to abide by the rules and "not to be led aside by subtle distinctions and considerations of hardships in particular cases; otherwise one uncertainty would arise after another, and the end would be inextricable confusion." 6 Eng. Rep. at 594; see 5 Eng. Rep. at 9. Lord Chancellor Lyndhurst felt the same way: "Under these circumstances, I conceive I am bound to say, that whatever private opmion, whatever conjectural opinion, I may entertain respecting the imtention of the testatrix, the will is not an execution of the power . . . " 5 Eng. Rep. at 8 ; see 6 Eng. Rep. at 594.

The opinion of the Judges, which was adopted by the House of Lords, was delivered by Lord Chief Baron Alexander:

It is said that the present is a question of intention, and so perhaps it is. But there are many cases of intention, where the rules by which the intention is to be ascertained are fixed and settled.

It would be extremely dangerous to depart froin these rules, in favour of loose speculation respecting intention in the particular case.

It is, therefore, that the wisest Judges have thought proper to adhere to the rules I have mentioned, in opposition to what they evidently thought the probable intention in the particular case before them.

130 Eng. Rep. at 1365. To find an execution of the power in this case "would be to mdulge an uncertain speculation in opposition to positive rules." Id. at 1366.

102. 77 Eng. Rep. 279 (K.B. 1599). Other cases attempting to fulfill the testator's intent were Probert v. Morgan, 26 Eng. Rep. 281 (Ch. 1739); Wallop v. Earl of Portsmouth, Rolls, Apr. 25, 1752 , reprinted in SUGDEN app., at 916.

103. See text accompanying note 78 supra. 
dence necessary to support an inference of intent to exercise. These cases might have passed into history as merely the last aspect of the old formalism in interpreting written instruments, and changing rules on the admissibility of extrinsic evidence in the interpretation of wills would have rectified the problem in due course. However, the results of these cases were so unsatisfactory that the legislature intervened to correct them.

\section{STATUTORY REFORMS OF THE 1830S}

Law reform commissions in both England ${ }^{104}$ and New York ${ }^{105}$ studied the laws of real property and of wills during the 1820s and 1830s. Apparently working independently, both groups proposed sweeping reforms. Included in the enactments following their reports were sections governing the exercise of powers of appointment by general dispositions of property.

The New York statute, effective in 1830, provided: "Lands einbraced in a power to devise, shall pass by a will purporting to convey all the real property of the testator, unless the intent that the will shall not operate as an execution of the power, shall appear, expressly or by necessary implication."106 The principal features of this statute were that it applied to property subject to any power, whether general or special, that it literally applied only to real property, and that it would apply unless the intention not to exercise the power appeared in the will. ${ }^{107}$ The statute was extended by court decision to personal property in $1883 .{ }^{108}$

The English statute, enacted as section 27 of the Wills Act of $1837,{ }^{109}$ provided:

[A] general Devise of the Real Estate of the Testator . . . shall be

104. Commissioners were appointed to inquire into the law of real property in 1829 . They issued four reports in $1829,1830,1832$, and 1833 . The fourth report dealt with wills and probate and provided the foundation for the Wills Act of 1837, 7 Will. 4 \& 1 Vict., c. 26. 15 W. HoldsWORTH, A HISTORY OF ENGLISH LAW 167, 172 (1965).

The commissioners were presided over by John Campbell, later Chief Justice and Lord Cliancellor. They were W.H. Tinney, J. Hodgson, S. Duckworth, P.B. Brodie, L. Duval, and J. Tyrrell. F.W. Sanders did not sign the third and fourth reports. $15 \mathrm{~W}$. HoldsworTH, supra at 167.

105. The New York Revisers were appointed pursuant to an act passed Noveunber 27, 1824. The revisers were Erastus Root, Benjamin Butler, and John Duer. III N.Y. Rev. Stats. app., at 403 (1836).

106. I N.Y. Rev. Stats. pt. II, ch. 1, tit. 2, § 126 (1836) (effective date Jan. 1, 1830).

107. See Lockwood v. Mildeburger, 159 N.Y. 181, 53 N.E. 803 (1899).

108. Hutton v. Benkard, 92 N.Y. 294 (1883). The court held that there was no sense in having different rules for personal property and for real property. It thus applied the statutory rule to personal property by analogy.

109. 7 Will. 4 \& 1 Vict., c. $26, \S 27$. 
construed to include any Real Estate . . . which he may have Power to appoint in any Manner he may think proper, and shall operate as an Execution of such Power, unless a contrary Intention shall appear by the Will; and in like Manner a Bequest of the Personal Estate of the Testator ... described in a general Manner, shall be construed to include any Personal Estate ... which he may have Power to appoint in any Manner he may think proper, and shall operate as an Execution of such Power, unless a contrary Intention shall appear by the Will. ${ }^{110}$

Unlike the New York statute, the Enghsh statute applied only to general powers and expressly covered both real and personal property. The English statute also applied to any general devise or bequest, whether or not it purported to convey all of the testator's property. The English statute, like the New York statute, presumed that the testator intended to exercise the power unless a contrary intent appeared in the will.

Although the New York Revisers and the English Real Property Commissioner both made reports explaining much of their proposed legislation, ${ }^{111}$ neither group's report contams any explanation of these two statutes. ${ }^{112}$ We are not told of the problem to which the statutes

110. Id.

111. The report of the New York Revisers is printed in the appendix to Volume 111 of the Revised Statutes. III N.Y. Rev. Stats. app., at 403-863 (1836). The Fourth Report of the English Real Property Coinmissioners is separately published. The Author is grateful to the law library at the University of California, Berkeley, for having graciously made a copy of this report available.

112. The first paragrapls of the Fourth Report of the English Commissioners is as follows: "We, who have liereunto subscribed our Names and affixed our Seals, Commissioners appointed by Your Majesty to inquire into the Law of England respecting Real Property, liumbly present to Your Majesty the result of our deliberations on the subject of Wills, except that part of it which respects their construction." Fourth Report of the English Real Property Commissioners 1 (1833) (emplrasis added). This suggests that there may have been another report in whicl the question whether a will should exercise a power was considered. The only proposal in this report relating to the exercise of powers by will is Number 6 , that any will made in exercise of a power shall be executed in the same manner as is required for other wills. Id. 80 .

The Report does not contain any reference to wliat was to become section 27 of the Wills Act, suggesting either that it was the subject of the separate report contemplated on the construction of wills (which we may assume was never made, both from our failure to locate it and from Holdsworth's failure to mention it) or that it had a separate genesis entirely. See note 114 infra.

The New York Revisers' report concentrates on the formalities of execution and criticizes the equity doctrines assisting defective execution. It makes no mention of the reason for section 126. Revisers' Reports and Notes, III N.Y. Rev. Stats. app., at 587-88, 591-92. The Reports make two coinments that are of note:

The law of powers, as all who have attempted to master it, will readily admit, is probably the most intricate labyrintl in all our jurisprudence. Few, in the course of their studies, have been called to enter it, who have not found it difficult to grope their way in its numerous and winding passages. In plain language, it abounds pre-emmently in useless distinctions and refinements, difficult to be understood, and difficult to be applied, by which a subject, in its own nature free from embarrassment, is exceedingly perplexed and darkened.

Id. 588 . 
were addressed or of the reasons for adopting the statutes' approach. However, it is possible to adduce an explanation from the case law and literature that formed the background for the adoption of the statutes.

A striking feature of both statutes is that property subject to a power is treated as if it were property owned by the donee for the purpose of deterunining whether it passes by a general gift or residuary clause. ${ }^{113}$ In other words, neither statute distinguishes between assets the donee owns and those over which he has only a power. This suggests that the statutes were designed to address the criticism of the case law frequently voiced prior to 1830: that the difficulties were caused by the courts' insistence on distmguishing power and property. ${ }^{114}$

As discussed above, ${ }^{115}$ Sir Thomas Plumer in Jones v. Curry ${ }^{116}$ felt bound to hold the power not exercised even though convinced that the donee had imtended to exercise it. He attributed this result to the dis-

In conclusion we remark, that on the subject of powers, the legislature may act with entire safety. They will disturb nothing. Powers are almost unknown in this state, and their use to the extent in which they are now authorized by law, is hardly consistent with our habits of society and general modes of alienation. In England, it is true, powers are found in almost every conveyance or settlement, and they are there of admirable use im perpetuating estates in families, and securing the possessions and power of a landed aristocracy. It is not surprising, therefore, that powers should be favored in England; for the continuance of the landed property of the kingdom, in the hands of its aristocracy, is the basis upon which the monarchy itself may be said to rest; but with us, it should never be forgotten, that it is the partibility, the frequent division, and unchecked alienation of Id. 592. property, that are essential to the health and vigor of our republican institutions.

113. Under both statutes, a general disposition of property in the donee's will disposes of the appointive assets, passing them as if they were owned by the donee. The English statute limits this treatment to assets subject to a general power; the New York statute applies it to assets subject to any power. Of course, the New York statute has not been applied to exercise special powers when the residuary takers under the donee's will were not objects of the power. To this extent, the assets are not treated as if they belonged to the donee.

114. See notes 80-95 supra and accompanying text. Chief Justice Denio in White v. Hicks, 33 N.Y. 383 (1865), offers the following observations about passage of the English statute:

Any person who will examine the cases in which the rule I have been considering [that if the donee owns property on which the devise can operate, it cannot exercise the power] has been applied, and the remarks of the English systematic writers, and who will call to mind the manner in which British statutes relating to civil jurisprudence and the laws of property are now framed, namely, on the recommendation of the lord chancellor, and after consultation with the judges of the higher courts, will not for a moment doubt but that the change was made to get rid of an unjust rule which had become too firmly established by the courts to be otherwise abrogated. . . . He [Sugden] . . . thought, apparently, that the mischief might better be remedied by the courts. . . . He was overruled, or perhaps changed his inind, for the act appears to have been passed the year succeeding that in which the edition containing the remark I have quoted was published.

Id. at 407. What this suggests, of course, is that section 27 of the Wills Act may not have been the work of the Real Property Commissioners at all, but rather of Lord Chancellor Lyndhurst or Brougham (1827-1830). Lyndhurst's remarks in Denn v. Roake, 5 Eng. Rep. 1, 6 Eng. Rep. 589 (H.L. 1830), may support this lypothesis. See 5 Eng. Rep. at 7-9, 6 Eng. Rep. at 593-94.

115. See note 94 supra and text accompanying notes $92-94$ supra.

116. 36 Eng. Rep. 300 (Ch. 1818). 
tinction drawn between power and property. ${ }^{117}$ Sugden, Lord St. Leonards, the preeminent authority on powers of appointment of that time, ${ }^{118}$ had commented, "[i]n reviewing the cases . . . it is impossible not to be struck with the number of instances where the intention has been defeated by the rule distinguishing power from property." 119 If these statements are read literally, without examining the cases that generated them, ${ }^{120}$ it would appear that the principal authorities of the time believed that the problem of execution of powers by implication could be resolved by assimilatimg property and power or, in other words, by treating property over which the testator had a power as if it belonged to the testator. ${ }^{121}$ This is certamly what the New York statute

117. Id. at 303. Plumer stated:

It is now clear that the Court cannot look beyond the will. Whatever is the inadequacy of a testator's property to satisfy the terms of the will, and whatever may be the conviction of the Court of his intention to execute the power, the state of his personalty, at the time of the will or of the death, cannot be examined for the purpose of collecting evidence of his intention. . . .

The distinction ... being now established between property and power, these words, containing no direct reference to any particular fund, nothing im description to enable the Court to collect her intention to exercise her power, are not sufficient to designate with due certaimty, property not her own, but of which she was empowered to dispose.

Id. at 302. See Blagge v. Miles, 3 F. Cas. 559 (C.C.D. Mass. 1841) (No. 1,479); White v. Hicks, 33 N.Y. 383 (1865).

118. 16 W. Holdsworth, A History OF ENGlish LAw 46-52 (1965), discusses Sugden's work as an author. His treatise on powers appeared in 1808. Subsequent editions appeared in $1815,1821,1826,1831,1836,1845$, and 1861 .

119. SUGDEN 338. The only edition available to the author is the eighth English edition published in 1861 . Presumably the criticism he voiced in 1861 was the same he made prior to 1837 . See White v. Hicks, 33 N.Y. at 407 . E. Sugden, A Practical Treatise on the New Statutes ReLATING to Property (2d ed. 1862), discusses the operation of section 27 of the Wills Act but does not explain its origin. Id. 376-79. This work was graciously loaned by the Library of Congress.

120. See text accompanying notes 81-94 supra. See also Bradly v. Westcott, 33 Eng. Rep. 361 (M.R. 1807), in which the wife was given a life interest with power of disposal and a testamentary power of appointment over $£ 500$. Her will did not mention the power. The court held that the same words that disposed of her own property could not exercise the power because

[i]f that would be sufficient, there is no distinction between power and property. The distinction is perhaps slight, which exists between a gift for hife, with a power of disposition superadded, and a gift to a person indefinitely, with a superadded power to dispose by Deed or Will. But that distinction is perfectly established; that in the latter case the property vests.

Id. at 363 .

121. This had almost been suggested by Sir R.P. Arden, Master of the Rolls, in Langham v. Nenny, 30 Eng. Rep. 1109 (M.R. 1797): "I rather wish, the Court had taken another lime in these cases; and had held, that any general words be sufficient to execute such powers: but I am not at liberty to say so." Id. at 1111 .

Lord Loughborough's view in Standen v. Standen, $30 \mathrm{Eng}$. Rep. 791 (Ch. 1795), was that the property subject to the general power should be treated as the donee's own. Id. at 792. There were also cases in which the court found that in fact the property subject to the power belonged to, or should be treated as if it belonged to, the donee. E.g., Hixon v. Oliver, 33 Eng. Rep. 235 (Ch. 1806); Hales v. Margerum, 30 Eng. Rep. 1021 (M.R. 1796). In these cases property would have 
did, and, to a more limited extent, the English statute did the sameapplying only to general powers. ${ }^{122}$

The reformers failed to realize, however, that Sugden's criticism of the distinction between power and property imvolved a considerably more complex set of thoughts. In Nannock v. Horton, ${ }^{123}$ the first case in which the court complaimed that "the rule" defeated the donee's intent, Lord Eldon reasoned that the words "my estate" or "my property" were not ambiguous ${ }^{124}$ and that extrinsic evidence offered to prove that the testator had intended them to refer to appointive property must be excluded. ${ }^{125}$ Sugden and other cominentators were criticizmg this entire approach: the words "iny estate" did not have a single fixed ineaning, and extrinsic evidence should have been allowed to show that the donee meant property subject to the power as well as property that he owned.

The reformers' failure to appreciate the subtlety of this distinction led directly to their failure to solve the problems created by the case law. Their statutes abolished the distinction between property and power for purposes of determining what passed under a general disposition of property im the donee's will ${ }^{126}$ but left intact the rule excludimg

been given outright except for the donee's disability of marriage, and the power was given to enlarge the rights of the donee over the property, not to limit them. No distinction is made in the statutes based on the status of the donee or the reason for creation of the power.

122. The statute applied to property that the testator "may have power to appoint in any manner he may think proper." Wills Act of 1837, 7 Will. 4 \& 1 Vict., c. 26, § 27.

123. 32 Eng. Rep. 158 (Ch. 1802). See notes 75 \& 81-83 supra and text accompanying notes $71-87$ supra.

124. 32 Eng. Rep. at 162. Plumer said in Webb v. Honnor, 37 Eng. Rep. 410 (M.R. 1820):

There is not on the face of the will any reference to the power, that is not necessary to make it a good execution, but the defect must be supplied by very clear internal evidence of the intention. Now in this imstrument, there is nothing to show that the testator meant to dispose of any thing but lis own property; every part of it is satisfied by giving all that he was possessed of. . . . It would . . . be impossible by any evidence to show an intention in this will to pass property not belonging to himself, but over which he had a power.

Id. at 412 .

125. The Connecticut court in Hollister v. Shaw, 46 Conn. 248 (1878), echoes this view: "We are not permitted to declare that power and property are synonymous terms, and therefore cannot say that the expression 'my estate' . . . includes the subject of the power." Id. at 255.

126. It is certainly possible that the rationales underlying the two statutes were different. The English statute may well have been based on the idea that where the power is general, the donee is very much like the owner of the property and should be treated as such for purposes of determining whether he intended to dispose of the property. If so, the statute extended the approach found in some of the married women's property cases to all general powers and adopted Lord Alvanley's suggestion from Langham v. Nenny, 30 Eng. Rep. 1109 (M.R. 1797). See note 69 supra.

This rationale cannot be extended to the New York statute, however, as that statute apphes to special powers as well, which certainly cannot be equated with ownership of the property. The only underlying rationale that inakes sense here is an assumption that the donee of a power will always want to exercise it because he will always prefer his legatees and devisees to the takers im default. See Rabin, Blind Exercises of Powers of Appointment, 51 Cornell L.Q. 1 (1965). 
extrinsic evidence. ${ }^{127}$ The statutes merely reversed the presumption against intent to exercise; they did nothing to allow courts more freedoin in ascertaining the donee's intent. In fact, the statutes further limited the courts' ability to consult extrinsic evidence. Prior to the statutes, the courts considered evidence that the donee did not own the property specifically devised or bequeathed; after the statutes, courts were directed not to consider any extrinsic evidence of intent not to exercise.

Thus, the net result of the enactment of the New York and Enghish statutes was to reverse the rule that a general disposition would not exercise a power, but to leave intact, to tighten, and indeed to set into the concrete of statutory law the rule against extrinsic evidence established by the Courts of Chancery between 1739 and 1830. The new rule on exercise was no less arbitrary than the old.

In the following half century, these two statutes served as models for legislation in a number of jurisdictions across the United States. The English statute was the nodel for the Eastern Seaboard states; ${ }^{128}$ the New York statute was the model for states in the Midwest and Far West. ${ }^{129}$ Altogether, seventeen states ${ }^{130}$ enacted statutes providing that a general devise or bequest would exercise a power in the absence of a manifestation of contrary intent in the will. ${ }^{131}$

These clear statutory rules, however, did not end hitigation on the

The proposition that the bases for the two statutes differ may find support in the relative sophistication of the two groups. It seems far inore likely that the New York revisers were unfamiliar with the context of the statements about distinguishing power and property than the Enghish would have been.

127. The New York statute, see text accompanying note 106 supra, requires that the intent that the will not operate as an exercise appear "either expressly or by necessary implication." The English statute, see text accompanying note 110 supra, requires exercise "unless a contrary Intention shall appear by the Will."

128. North Carolina, Pennsylvania, Rhode Island, Soutl Carolina, Virginia, and West Virginia adopted statutes based on the English model. These statutes are still in effect and are cited in their current form in notes 30-31 \& 33 supra. The old Maryland statute, enacted in 1888, was also based on the English inodel. MD. ANN. CODE art. 93, § 359 (1957) (repealed MD. Est. \& TRusts CODE ANN. \$ 4-407 (1976)). The District of Columbia statute was probably inodeled on the Enghish statute as well. D.C. Code ENCYCL. $\$ 180-303$ (West 1967).

129. California, Kentucky, Michigan, Minnesota, Montana, North Dakota, Oklahoina, South Dakota, Utah, and Wisconsin all had statutes that were patterned after the New York inodel. See Restatement $\$ 343$, Comment d, for a list of statutes in effect on January 1, 1940. See also 5 AMERICAN LAw OF Property \$ 23.40, at 563 n. 15.

130. This number does not mclude the District of Columbia.

131. All those patterned on the English Act were limited to general powers. The Pennsylvania court, however, held that a residuary clause would exercise a special power when the devisees were the same as the objects of the power. In re Lafferty's Estate, 311 Pa. 455, 167 A. 44 (1933). The Kentucky statute applied to "discretionary" powers. In MacLean v. Citizens Fidelity Bank \& Trust Co., 437 S.W.2d 766 (Ky. 1969), the court held this language limited the statute to general powers. In 1972 the statute was amended to eliminate the word "discretionary," so that it now 
question. On the contrary, the American statutes have generated a considerable body of case authority. ${ }^{132}$ As with the English cases decided before the statutes, ${ }^{133}$ the most troublesome cases are those in which it is clear that the donee did not intend to exercise the power, but in which the court refused to consider, or deemed itself precluded from considering, evidence proffered to show the donee's intent.

\section{A Sample of Troublesome Cases Under the 1830s STATUTES}

Four modern cases, two decided under the New York statute ${ }^{134}$ and two decided under the California statute, ${ }^{135}$ clearly illustrate that these reform statutes did not cure the problems of the pre-1830 case law. In re Deane's Will ${ }^{136}$ involved an inter vivos trust created in 1932 in New York. The life beneficiary, Ms. Deane, held a general power over the corpus of the trust, which was worth roughly $\$ 800,000$ when she drew her will. The takers in default of appointment were the donee's son as to two-thirds of the trust estate and her sister as to onethird. Ms. Deane's will inade her infant grandson the sole legatee. The grandchild was the only child of her son, one of the takers in default.

Evidence was offered that there was a close and affectionate relationship between the testator and her son, that the will was drawn in Texas when the testator was visiting her son and his wife, that the son and his wife were not wealthy, and that the testator had been in the habit of giving thein generous financial assistance. ${ }^{137}$ The attorney who

applies to any power. Ky. Rev. Stat. ANN. \$ 394.060 (Baldwin Supp. 1976) (amending Ky. Rev. STAT. ANN. \& 394.060 (Baldwin 1969)).

132. See cases collected in Annot., 15 A.L.R.3d 346 (1967), and Annot., 16 A.L.R.3d 911 (1967).

133. See notes $42-103$ supra and accompanying text.

134. I N.Y. Rev. Stats. pt. II, ch. 1, tit. 2, § 126 (1836) (effective date Jan. 1, 1830).

135. Wills Act $\$ 22$, ch. 72,1850 Cal. Stats. 179 (current version at CAL. Prob. Code $\$ 125$ (West Cum. Supp. 1979)). The California statute was based on the New York statute, see text accompanying note 106 supra. As reenacted in 1931 as Probate Code $\$ 125$, ch. 281, 1931 Cal. Stats. 594 (codified at CAL. PROB. CoDE $\$ 125$ (West 1956)), it read:

A devise or bequest of all the testator's real or personal property, in express terms, or in any other terms denoting his intent to dispose of all his real or personal property, passes all the real or personal property which he was entitled to dispose of by will at the tine of his death, including property embraced in a power to devise.

This statute was amended by part of the Powers Act of 1970, ch. 155, 1969 Cal. Stats. 409. The Powers Act took powers of appointment out of the operation of the Probate Code section 125 and added new sections to the Civil Code to govern such powers. 1969 Cal. Stats. 405. The new sections, codified at CaL. CIv. CoDE $\$ \S 1386.1-.2$ (West Cum. Supp. 1979), differ from the old statute in many respects. Section 1386.2, applying only to general powers, is set out in text accompanying note 265 infra.

136. 4 N.Y.2d 326, 151 N.E.2d 184, 175 N.Y.S.2d 21 (1958).

137. Id. at 332, 151 N.E.2d at 187, 175 N.Y.S.2d at 25. 
drew the will also testified that the testator told him that her own estate consisted of $\$ 50,000$ to $\$ 60,000$, and that in addition she had an income from a trust that would take care of her son and her sister. The attorney testified further that at this poimt he and the testator agreed that the trust need not be mentioned in the will. Although the opinion did not mention the fact, in Texas no presumption of intent to exercise is drawn from a general disposition in the donee's will. ${ }^{138}$

The court held that none of this evidence was admissible because "the proof to rebut the statutory presumption must be found in the will itself, as the statute expressly says, and there was nothing in this will to that effect."139 The court emphasized that it had long held that the "contrary intent" must appear in the will: "Long ago, in Lockwood $v$. Mildeberger ... . we emphasized that the intent not to execute the power must appear in the will itself either expressly or by necessary imphication and that such a Necessary imphication results only where the will permits of no other interpretation' . . ."140 This standard of "necessary implication" was the same as that stated in Andrews v. Em$m o t^{141}$ and applied by the English courts prior to $1830 .{ }^{142}$

The trial court had differentiated between the testimony concerning the testator's statements, which was stricken, and the other evidence about her assets and family relationships, holding the latter admissible but insufficient to overcome the statutory presumption. ${ }^{143}$ The Court of Appeals held that none of the evidence was admissible, but did agree with the trial court that, even if it had been allowed, it was not strong enough to overcome the statutory presumption. ${ }^{144}$ Thus, the son and the sister received nothing, while the infant grandson received over three quarters of a million dollars.

138. See Republic Nat'l Bank v. Fredericks, 155 Tex. 79, 89-90, 283 S.W.2d 39, 46-47 (1955). 139. 4 N.Y.2d at $333,15 I$ N.E.2d at 188,175 N.Y.S.2d at 26.

140. Id. at 330, 151 N.E.2d at 185,175 N.Y.S.2d at 23 (quoting Lockwood v. Mildeberger, 159 N.Y. $181,186,53$ N.E. 803,804 (1899)).

141. 29 Eng. Rep. 162 (Ch. 1788). See notes $63,65-67$ supra and text accompanymg notes 61 67 supra.

142. See cases discussed in text accompanying notes 68-103 supra.

143. 4 N.Y.2d at $333,15 I$ N.E.2d at 187 , 175 N.Y.S.2d at 26.

144. The court said:

We liold that, because of the express language of section 18, this proof was not even admissible on the question of whether this will exercised the power of appointment. But, even if it were admissible (that is, everything except the statements of testatrix), it clearly would not rebut the statutory presumption that a general bequest exercises the power of appointment.

Id. The section 18 that the court mentions here is Act of Feb. 17, 1909, ch. 45, § 18, 1909 N.Y. Laws 18 (codified at N.Y. Pers. Prop. LAw $\S 18$ (McKinney 1962)) (repealed 1967). This section extended the application of the original statute, see text accompanying note 106 supra, to personal property. 
In a more recent New York case, Estate of Beckwith, ${ }^{145}$ frustration of the testator's imtent was only narrowly averted. There the testator's husband created a marital deduction trust, giving the testator a general power to appoint "by her deed delivered by her in her lifetime to iny said Trustee." 146 In default of appointment, the corpus belonged to their daughter. The testator's will did not mention the power but contamed a residuary clause leaving her property to four charities. ${ }^{147} \mathrm{Be}-$ tween the execution of the husband's will and his death, a statute had been enacted providing that a power exercisable only by deed was also exercisable by will, unless such exercise was expressly excluded. ${ }^{148}$ When his will was executed, a power exercisable only by deed was not exercisable by will. ${ }^{149}$

The testator's will, in addition to naming the four charities as her residuary takers, recited that she had made no inonetary bequests to her daughter or her family because they were well provided for by her husband's will and a government pension. ${ }^{150}$ Since the husband's will had created a residuary trust as well as the marital deduction trust, and the residuary trust was substantial, the trial court held that the donee's will did not express a clear intention not to exercise the power. ${ }^{151}$ The appellate division reversed on the basis that the language of the husband's will was such as to preclude exercise by will, falling within the exception of the statute. ${ }^{152}$ Had the court not found that the husband "expressly excluded" the possibility of exercising the power by will, however, the assets of the marital deduction trust would have passed to the charities, instead of to the daughter, and the decision would have frustrated the clear intent of the donee. ${ }^{153}$

In a California case mvolving a marital deduction trust, Estate of Carter, ${ }^{154}$ the operation of the statute similarly resulted in the exercise

145. 57 App. Div. 2d 415, 395 N.Y.S.2d 499 (1977), modiffying 87 Misc. 2d 649, 366 N.Y.S.2d 615 (1976).

146. 57 App. Div. $2 d$ at 416,395 N.Y.S.2d at 501.

147. 87 Misc. $2 d$ at 649,386 N.Y.S.2d at 617.

148. Act of Apr. 23, 1964, ch. 864, § 148.3, 1964 N.Y. Laws 2327 (originally codified at N.Y. Real Prop. LaW § 148) (now codified at N.Y. Est., Powers \& Trusts Law § 10-6.2(3) (McKinney 1967)): "Where the donor has made the power exercisable only by deed, it is also exercisable by a written will unless exercise by will is expressly excluded." 57 App. Div. 2d at 416, 395 N.Y.S.2d at 501.

149. 57 App. Div. 2d at 417,395 N.Y.S.2d at 501 . In the absence of a statute, a power exercisable by deed is not exercisable by will. 3 Powel, supra note 3, I 398 , at 378.40 .

150. 87 Misc. $2 \mathrm{~d}$ at 656,386 N.Y.S.2d at 619.

151. Id. at $656-57,386$ N.Y.S.2d at 620 .

152. 57 App. Div. at 417-18, 395 N.Y.S.2d at 501-02.

153. There was no question that the residuary clause would have exercised the power if the power had been exercisable by will. See 87 Misc. 2d at 656-57, 386 N.Y.S.2d at 620.

154. 47 Cal. 2d 200, 302 P.2d 301 (1956). 
of a power contrary to the donee's intent. In that case, the taker in default of the wife's exercise of her power was the "B," or residuary, trust created by the husband's will. There were twenty-eight named specific beneficiaries of that trust, and the residue was payable to the Church Divinity School of the Pacific. The wife's will was executed at the same tinie as the husband's, shortly after enactment of the marital deduction provision. ${ }^{155}$ The wife's will, inaking no reference to the power, gave the residue of her estate to the divinity school. After the husband's death, the wife executed a codicil adding five more charities to her residuary bequest. The wife's will and codicil were drawn by the same attorney who drew the husband's will. The attorney testified that the wife did not intend to exercise her power either by the will or by the codicil, and that he had advised both her and her husband that she could exercise her power only by a will or codicil executed after her husband's death and only if the will or codicil contained language of express exercise. ${ }^{156}$ On the basis of this testiniony, the trial court found that the wife did not intend to exercise the power.

The Cahifornia Supreme Court reversed, holding that nothing in the wife's will indicated that she did not imtend to exercise the power. The court's rationale for excluding the attorney's testimony, however, is interesting. Rather than simply stating that the statute precluded the admission of evidence extrnusic to the will, the court held the attorney's testiniony inadmissible because there was no ambiguity in the will, either in the identification of beneficiaries or in the description of the property. ${ }^{157}$ Once again, the court's analysis is similar to the reasoning

155. I.R.C. $\$ 2056(b)(5)$ provides that a hife estate coupled with a general power of appointment given to the spouse will qualify for the marital deduction.

156. $47 \mathrm{Cal} .2 \mathrm{~d}$ at $203,302 \mathrm{P} .2 \mathrm{~d}$ at 303 . This advice was not even reasonable when given, smce the court in California Trust Co. v. Ott, 50 Cal. App. 2d 715, 140 P.2d 79 (1943), had apphed the statute to a power acquired after execution of the will.

157. 47 Cal. $2 d$ at 206,302 P.2d at 305 . The court held it error to admit the attorney's testimony concerning the testator's declarations because such testimony is admissible only where there is a latent anbiguity in identification of beneficiaries or in description of property. Id. at 207-08, 302 P.2d at 306-07. This holding standing alone is consistent with much authority excludimg declarations of the testator's intent (even when other extrinsic evidence would be admissible) except in case of an equivocation. 4 Bowe \& PARKER, supra note 24, § 32.9. However, it is coupled with statements that the language of the will was clear and unambiguous with respect to exercise of the power. Apparently the court viewed the statute as giving a clear content to the language of the residuary clause. This position is like that of Lord Eldon. See text accompanying notes 80-83 supra.

Of course, it is possible to view the court's statement as dictum, because it does not appear that any evidence of her intent not to exercise the power was offered except for the attorney's testimony, and that would have been inadmissible in several courts that would otherwise have considered extrinsic evidence on the question of her intent. See note 24 supra. At least one California case, however, would admit the attorney's testmony while excluding other evidence of testator's declarations. In re Estate of Moulin, 101 Cal. App. 2d 221, 225 P.2d 303 (1951). 
of Lord Eldon. ${ }^{158}$ The only difference is that, to the California court, "my property" unambiguously included property subject to a power. ${ }^{159}$

In California Trust Co. $v$. Ott, ${ }^{160}$ the statutory presumption also apparently defeated the intent of the donee. The testator's will, executed in 1929, left the residue of his estate to his wife. In 1930 he created an inter vivos trust providing hife interests for himself and his wife, with remainder as he should appoint by will, and in default of appointment to his heirs determined as if he had died immediately after his wife. He died in 1930 and his wife died in 1941. The court held that by virtue of the statute ${ }^{161}$ his will executed the power. ${ }^{162}$ The incongruity involved in giving his wife a remaimder that was to become possessory only after her death ${ }^{163}$ and the fact that the power was created after the will was executed were not sufficient manifestations of a contrary intent to overcome the statutory presumption.

These four cases show that courts can, and indeed inay be required to, frustrate the apparent intent of the donee of a power as readily under the reform statutes of the 1830s as under the case law developed prior to the enactment of the statutes. At this point, the reason should be obvious: no rule that requires that a single meaning be given to words like "my property" can carry out the intent of all donees of powers who fail to state exphcitly their intent with respect to exercise. Not all donees intend to exercise their powers, nor do all donees intend not to exercise their powers. Language like "my property" simply does not reveal whether the donee intends to mclude the property subject to the power or not; in short, it is anbiguous. The 1830s statutes refused to recognize this ambiguity and thus created as much risk of frustrating the donee's intent as did the prior case law. The only difference between the statutes and court decisions is that in 1830, and for about a century thereafter, the case law suggests that more donees who failed to state their intent in fact did intend to exercise their powers than did not.

158. See text accompanying notes 80-83 supra.

159. The statute, of course, does not purport on its face to admit of any exceptions to its applieation, because it does not contain even the exception for a contrary intent expressed in the will.

160. 59 Cal. App. 2d 715, 140 P.2d 79 (1943).

161. See note 135 supra.

162. 59 Cal. App. $2 \mathrm{~d}$ at 718,140 P.2d at 81 . The court cited RESTATEMENT $\$ 344$ for the point that a power existing at the donee's death but created after the execution of his will is exercised if the will is an otherwise effective appointment. 59 Cal. App. $2 \mathrm{~d}$ at 718,140 P.2d at 81 .

163. On the imcongruity point, the court cited cases ineluding the life tenant annong the "heirs" to whom a remainder is limited. $59 \mathrm{Cal}$. App. $2 \mathrm{~d}$ at 718,140 P.2d at 81 . The analogy does not seem quite apt, since "heirs" has a much more fixed meaning than the language of a general disposition in the context of determining intent to exercise a power acquired after execution of the will. 
In this regard, the statutes probably resulted in fewer frustrations than did the judicial doctrines before thein. ${ }^{164}$

\section{Development of the American Common law}

By 1830 the English courts had developed the position that a disposition of property in the donee's will exercised a power only if the dispositive language would be otherwise ineffective. As a result, only a specific devise or bequest in the donee's will could exercise a power, ${ }^{165}$ and the English courts after 1800 often reached results that clearly frustrated the donee's intent. The American courts, however, led by Justice Story, took a more flexible approach and consequently were able to avoid many of the probleins created by the strict Enghish rules.

In Blagge v. Miles, ${ }^{166}$ Justice Story conducted an exhaustive review of the Enghish authorities and concluded that the fundamental principle underlying the cases was "that if the donee of the power intends to execute, and the mode be, in other respects, unexceptionable, that intention, however manifested, whether directly or indirectly, positively

164. When the powers were used to give married women the ability to devise and otherwise convey property, and when they were given to a surviving spouse who also took a possessory life interest in the property, presuming an intent to exercise would no doubt have carried out the intent of the average donee more often than it would have frustrated it. In these cases the purpose of creating the power was usually to give the donee as many of the benefits of ownership as possible without the disabilities of ownership. When, however, the power was created in connection with an inter vivos trust and was retained by the settlor, it is more difficult to draw conclusions as to the donee's intent. It is, of course, impossible to know in how many situations the intent of a donee was frustrated by the rules presuming an intent to exercise or an intent not to exercise. What does seem clear is that not all donees are the same, and an infexible rule cannot avoid frustrating the imtent of some.

165. Because wills of real estate were not ambulatory until the Wills Act of 1837,7 Will. 4 \& 1 Vict., c. 26, a devise of real estate required no particular description to be a "specific" devise. See note 65 supra.

166. 3 F. Cas. 559 (C.C.D. Mass. 1841) (No. 1,479). The most quoted portion of the opinion is the following:

Three classes of cases have been held to be sufficient demonstrations of an intended execution of a power: (1) Where there has been soine reference in the will, or other instrument, to the power; (2) or a reference to the property, which is the subject, on which it is to be executed; (3) or, where the provision in the will or other instrument, executed by the donee of the power, would otherwise be ineffectual, or a mere nullity; in other words, it would have no operation, except as an execution of the power.

Id. at 566. In a note to the decision, Justice Story observed:

It may not be unimportant to state, that all these refined and subtile distinctions, in relation to the execution of powers, are now swept away in England by the statute of wills . . . which has declared, that a general devise of real or personal estate, shall operate as an execution of a power of the testator over the same, unless a contrary intention shall appear on the will. The doctrine, therefore, has at last settled down in that country, to what would seein to be the dictate of common sense, unaffected by technical niceties. $I d$. at 570 , note. The comment is interesting because Justice Story failed to note that the statute prevents consideration of evidence of intent that does not appear in the will. 
or by just implication, will make the execution valid and operative."167 Story then enunciated a standard considerably less stringent than that applied by the English courts: ${ }^{168}$ the donee's mtent "must be apparent and clear, so that the transaction is not fairly susceptible of any other interpretation." 169

The New York Court of Appeals in White v. Hicks ${ }^{170}$ furthered this effort to escape the rigidity of the English decisions by pointing out that only those cases decided prior to the American Revolution were binding on American courts. ${ }^{171}$ The cases decided before the Revolution included only those through Lord Hardwicke's time, ${ }^{172}$ which appear to have carried out the donee's intent in every case. ${ }^{173}$ The court in White also adopted the modern approach to interpretimg wills and did not hesitate to consult extrinsic evidence for assistance in determming the donee's intent. ${ }^{174}$

The donee in White held a power of appoimtment over a trust fund of $\$ 50,000$. Her will, made shortly before her death, did not mention the power, but gave $\$ 50,000$ to her husband and made other legacies totalling $\$ 32,000$. At the time of her death, lier own property apart from her personal effects amounted to only $\$ 53,950 .{ }^{175}$ To prove her intent to exercise the power, evidence was offered to show that she was aware of the extent of her own property and of the existence of her power, that she made the will in expectation of imminent death, that her own funds were managed by the trustees of the appointive fund, and that the ternns of the trust that created the power suggested a gift of the fund to her liusband might be appropriate. In addition, evidence of the donee's declarations of intent to exercise the power was offered. The court excluded the testator's declarations of imtent but held the balance of the evidence admissible, finding that she had exercised the

167. Id. at 566 .

168. The English standard was that the evidence of intent to exercise must be conclusive: it must be impossible to attribute any other intent to the donee. Andrews v. Emmot, 29 Eng. Rep. 162 (Ch. 1788).

169. $3 \mathrm{~F}$. Cas. at 566.

170. 33 N.Y. 383 (1865).

171. Id. at 403.

172. Sir Edward Clere's Case, 77 Eng. Rep. 279 (K.B. 1599); Probert v. Morgan, 26 Eng. Rep. 281 (Ch. 1739); Molton v. Hutchinson, 26 Eng. Rep. 351 (M.R. 1739); see Ex parte Caswall, 26 Eng. Rep. 351 (Ch. 1744); Churchill v. Dibben, 96 Eng. Rep. 1310 (M.R. 1753); Wallop v. Earl of Portsmouth, Rolls, Apr. 25, 1752, reprinted in SUGDEN app., at 916. No cases of any doctrinal iunportance appear from 1753 until Andrews v. Emmot, 29 Eng. Rep. 162 (Ch. 1788).

173. See text accompanying notes 68-72 supra. Molton v. Hutchinson, 26 Eng. Rep. 351 (M.R. 1739), may have been an exception, but since the evidence offered to show proof of the donee's intent to exercise is not reported, it is impossible to tell.

174. See text accompanying note 23 supra.

175. 33 N.Y. at 386. 
power by the gift of the $\$ 50,000$ to her husband. ${ }^{176}$

In a third case, Funk v. Eggleston, ${ }^{177}$ the search for the fundamental principles behind the English cases of the early 1800 s contimued. In the Funk case the donee held a life estate and a power of appointment created by lier husband's will in an undivided two-thirds interest in land. She purchased and owned outright the other undivided one-third interest. By her will she devised all her property to her daughters by a prior marriage, but she did not mention the power. The takers in default were the husband's brothers and sisters and their descendants, a group that nuinbered 222 people. ${ }^{178}$ The evidence showed that the testatrix owned several parcels of real estate on which her devise would operate. The court looked at the number and identity of the takers in default and at the takers under the testator's will and decided that she inust have intended to exercise the power. It buttressed its conclusion with the observation that the direction in the will to sell the real cstate would not make sense when apphed only to the undivided one-third interest she owned in the parcel of which the other two-thirds was subject to the power. ${ }^{179}$

The court found the basic principle of the Enghish cases in a stateinent of Lord Coke in Scrope's Case:180 "IQJuia non refert an quis inten-

176. Id. at 387-88, 407. The opinion contains a quite thorough and learned discussion of the English authorities. After discussing Andrews at length as the basis for the rule that no inquiry into the personal estate can be inade, the court concluded that the case was rightly decided, id. at 397 , but that the rule was inproperly stated. The opinion blamed the rule's subsequent rigid enforcement on Lord Eldon's statement in Nannock. Id. at 398. The court then rejected the rule: "It appears to us that the rule referred to is too narrow; and we have, moreover, the opinion of eminent English judges that it often frustrates the intention of the anthors of those instrunents." Id. at 406 . Interestingly enough, the opinion throws away only one-half line on the New York statute: "TThe English statute] contains a similar provision in regard to wills of real estate, the parliainent following in the last inentioned provision our act of 1830." Id. at 406.

177. 92 Ill. 515 (1879).

178. Id. at 521. Althongh the court characterized the takers in default as the husband's heirs, in fact they took under an express gift in default. "But, if my said wife shall survive her said granddaughter, then at lier death I desire iny brothers and sisters and their descendants shall have whatever remains of iny estate not disposed by iny said wife, in equal parts thereof." Id. at 520 .

179. Id. at 543 . Indeed, a direction to sell one-third would have had little meaning if the other two-thirds belonged to 222 people.

180. 77 Eng. Rep. 1143 (Wards 1613). Nicholas Scrope covenanted to stand seised in fee of the manors of Harleston and Mount to the use of himself, his wife Winefrid, and daughter Anne, for their lives, then to Anne and the heirs of her body. He reserved a power to revoke and appoint new uses by a writing subscribed in the presence of three witnesses. After Winefrid's death, Nicholas inarried Elizabeth, and in consideration of a jointure to be inade to Elizabeth, Nicholas convenanted to stand seised of the manor of Harleston to the use of Nicholas and Elizabeth for their lives and then to the use of the right heirs of Nieholas. The court held that even though he did not mention the power to revoke, he sufficiently manifested his intent to revoke the prior uses when he limited new and other uses. 
tionem suam declaret verbis, an rebus ipsis, vel factis." 181 To explain the importance of Coke's rule, the court quoted from the opinion of Chief Justice Best in Doe v. Roake: ${ }^{182}$

The rule given by Lord COKE is larger than that which has been deduced from the decision in Clere's case. Lord COKE's Rule will be complied with, if the intention to execute a power be unequivocally manifested by any circumstances occurring in the case, or any act of the owner of the power, without requiring any specified overt acts of such intention. ${ }^{183}$

Although the court in Funk did not go far beyond the will in its search for the testatrix' intent, the case is notable for the hiberal attitude displayed by the court and for the inferences the court was willing to draw from the evidence. ${ }^{184}$

The Blagge, White, and Funk cases laid the foundation for the American coinmon law of exercise of powers of appointment by implication. They started with the fundainental principle of the Enghish cominon law that exercise of a power requires an affirmative manifestation of the donee's intent, ${ }^{185}$ but they avoided the problems created by

181. 77 Eng. Rep. at 1144 (footnote omitted). The English translation is "it is immaterial whether the intention be collected from the words used or the acts done." BLACK's LAw DICTIONARY 1122 (5th ed. 1979).

The Latin phrase appears in the following context:

Yet forasmuch as by the said indenture of 33 Eliz. he covenanted to stand seised to the use of himself, and the said Elizabeth, then his wife, and afterwards to his right heirs, it inured to two intents. 1. To declare his purpose and determination to determine, disannul, \& c. and thereby ipso facto the former uses ceased. And 2d, the covenant in the same indenture inured to raise a new use to the said Nicholas and Elizabeth . . . and so it was resolved in a case in the King's Bench, between Frampton and Frampton, . . . quia non refert an quis intentionem suam declaret verbis, an rebus ipsis, vel factis. and when he limited new and other uses, he thereby signified his purpose to determine and alter the uses before.

77 Eng. Rep. at 1144 (footnotes and citations omitted).

The Latin phrase is quoted by the Funk conrt, 92 Ill. at 538. The saine quotation appears in Justice Story's opinion in Blagge v. Miles, 3 F. Cas. 559, 566 (C.C.D. Mass. 1841) (No. 1,479), where he characterizes it as positively affirming the primciple of Clcre's Case and gives the quoted portion as the reason for the rule. The courts in both cases probably picked up the quotation froin the opinion of Chief Judge Best of the Court of Coinmon Pleas in Doe v. Roake, 130 Eng. Rep. 398, 402 (C.P. 1825).

182. 130 Eng. Rep. 398 (C.P. 1825).

183. 92 Ill. at 538 (quoting 130 Eng. Rep. at 402) (emphasis added). Chief Judge Best's opinion held the power exercised on the ground that the direction to repair unequivocally inanifested the donee's intent to transfer the property subject to the power. This decision was reversed on appeal. See note 101 supra.

184. The only evidence the court appears to have relied on is the number and identity of the takers in dcfault, as contrasted with the identity of the takers under the will (her daughters). Since the testator clearly owned property on which the devise could operate, there was no need to hold that the language exercised the power in order to make the devise effective. There was, thus, no necessary inference of an intent to exercise.

185. See text accompanying notes 7-9 supra. See Restatement, Introductory Note to Topic 6 , at 1904. 
the English courts in two ways: first, by adopting a less stringent standard as to the ainount of evidence necessary to support an inference of intent to exercise, and second, by following the modern trend toward admitting extrinsic evidence.

Froin this base, American courts developed three distinct lines of authority. One line, begun by the Massachusetts courts after the decision in Blagge v. Miles, ${ }^{186}$ adopted a position quite different froln that taken in the rest of the country. In an 1863 case, Amory v. Meredith, ${ }^{187}$ the court adopted the rule of section 27 of the Enghish Wills Act of $1837^{188}$ as a rule of construction. Although notivated by the saine criticisms of the Enghish cases that prompted the liberalization evidenced in Blagge ${ }^{189}$ and White, ${ }^{190}$ the Massachusetts court went much further, adopting as a base the idea that any general disposition of property by the donee sufficiently manifested intent to exercise a power. ${ }^{191}$ Although the court could have stopped there, it went on to adopt the balance of the statutory rule, holding that its rule of construction apphed

186. 3 F. Cas. 559 (C.C.D. Mass. 1841) (No. 1, 479). This case is discussed in text accoinpanying notes 166-69 supra.

187. 89 Mass. (7 Allen) 397 (1863).

188. 7 Will. 4 \& 1 Vict., c. $26, \S 27$.

189. See text accompanying notes $166-69$ supra.

190. See text accompanying notes $170-76$ supra.

191. The court thoroughly criticized the English decisions:

The distinction between "power" and "property" is carefully preserved through all of thein; and the refinements and subtleties to which this distimction leads are great and perplexing.

But the inconvenience and injustice to which the English doctrine gave rise lave been a constant subject of remark by the judges who applied it.

89 Mass. (7 Allen) at 398-99. The court went on to say:

Lord St. Leonards [Sugden], the lighest authority on any question relating to this brancl of the law, says that, "in reviewing the cases, it is impossible not to be struck with the number of instances where the intention las been defeated by the rule distinguishing power from property."

It is not surprising that a course of decisions obnoxious to such criticisins should be at length controlled by legislation.

Id. at 400 . Then the court stated its reasons for adopting the English statutory rule:

We are aware of no decisions in this commonwealth, binding on us as an authority, which slould compel us to adopt a rule of construction likely, in a majority of cases, to defeat the intention it is designed to ascertain and effectuate. Seeking for the imtention of the testator, the rule of the English statute appears to us the wiser and safer rule ....

Id. Interestingly, the court did not mention the New York legislation.

Under the facts of the case, lowever, there was no doubt that the testator meant to exercise the power. She had created a management trust for lerself because sle was an invalid. On her death the trustees were to convey it to such persons as she should designate in leer will, and "upon ler death intestate, to her heirs at law." Id. at 397. Slie had little property outside the trust (all of it was managed by the trustees), and her will made substantially larger provisions for one brother's family than for the others. They would all liave shared equally as takers in default. 
only to general powers ${ }^{192}$ and prevented the consideration of any evidence that the donee did not intend to exercise the power unless that contrary intent appeared in the will. ${ }^{193}$

Although other courts have flirted with adopting the Massachusetts position, ${ }^{194}$ and it appeared that New Hampshire had adopted this

192. In Stone v. Forbes, 189 Mass. 163,75 N.E. 141 (1905), the court indicated in dictum that the rule might extend to special powers:

On principle there would seem to be no just ground for a distinction between general and special powers, so far as relates to the execution of the power before or after it is created. ...

.. .

... There would seem to be no good reason why the question whether a special power of appointment had been exercised should not be deternined by the same rules that are applied in other cases to the construction or interpretation of wills, or why the distinction between a power and property, which has resulted in many instances, as courts have been compelled to admit, in defeating the intention of the testator, should be adhered to in cases where, as in the present, the donee of the power has the use of the property for his life, and many not unnaturally or unreasonably have failed to distinguish between property strictly and technically belonging to him and that of which he has the use....

Id. at 196, 75 N.E. at I42-43. However, in Fiduciary Trust Co. v. First Nat'l Bank, 344 Mass. I, 181 N.E.2d 6 (1962), the court held that the rule of construction applied only to general powers. The court reasoned that special powers were not like general powers, and that the donee of a special power would not look at the assets as his own property. The court explained the basis for the rule:

[T]he canon is based on a presuned confusion by a testator between property he owns outright and that which he can dispose of by his will to anyone he wishes. The presumed confusion results from the nature and extent of his power of disposition and not from his right to enjoy and use the property during his hife.

Id. at 10,181 N.E.2d at $11-12$.

In Beals v. State St. Bank \& Trust, 367 Mass. 318, 326 N.E.2d 896 (1975), the court held that the presuunption did apply to a power that was general when created but was later cut down by release to a special power for tax reasons. A concurring opinion roundly criticized the decision in Fiduciary Trust for perpetuating the distinction between "power" and "property," which the court in Amory had rejected as causing too many refinements and subtleties. Although the judge cited both the English statute and Judge Story's comment, see note 166 supra, he failed to note that they applied only to general powers. His articulation of the rationale for the presumption was the following:

I am unable to accept the proposition that a testator who subscribes to a will which includes a residuary clause in substantially the common form . . . does not thereby express quite clearly an intention to dispose of all the property and estate which can be the subject of testamentary disposition by him. Neither am I able to accept the proposition that such language, reasonably construed, permits any inference that the testator intended, by the use of such broad language, to exercise a general power of appointment but not a special one.

367 Mass, at 328, 326 N.E.2d at 902.

193. Harvard Trust Co. v. Frost, 258 Mass. 319, 154 N.E. 863 (1927):

It is well settled that a devise of all one's property is presumed to include a general power of appointment, unless the contrary appears from the will. ... This rule excludes extrinsic evidence tending to show that the testator meant to inake a different disposition of his property from what appears on the face of the will.

Id. at 322,154 N.E. at 864.

194. In Bar Harbor Banking \& Trust Co. v. Preachers' Aid Soc'y, 244 A.2d 558 (Me. 1968), the Maine court, on the basis of ample extrinsic evidence, held that a residuary clause exercised a power. In the opinion, however, the court said: 
approach for about fifty years, ${ }^{195}$ the arbitrary nature of the rule ultimately led to its rejection both in New Hampshire ${ }^{196}$ and in Massachusetts. ${ }^{197}$ Simply adopting a presumption that a donee intends to exercise a power by a general disposition of property would have been an acceptable modification of the English common law, but when coupled with a rule preventing the consideration of any extrinsic evidence of the donee's actual intent, the rule, like the statute, operated too arbitrarily to produce satisfactory results. ${ }^{198}$

\section{The other two distinct lines of American authority adhered inuch}

In circumstances such as are present in the instant case where the donee or possessor of the general testamentary power knows that he has such power, the Massachusetts rule is the better serviceable device to reach and effectuate the factual testamentary intent, and to that extent we do adopt the Massachusetts doctrine.

Id. at 562 (emphasis in original). That the Mame court would adopt the portion of the rule excludimg extrinsic evidence of contrary intent seems doubtful in that Massachusetts has now repudiated the rule by statute. See note 197 infra and text accompanyimg note 227 infra.

The decision in Dollar Sav. \& Trust Co. v. Kirkham, 21 Ohio Misc. 163, 255 N.E.2d 892 (C.P. 1969), in which the court held that a residuary clause did not exercise a power, was apparently reversed in an unpublished opinion on the basis that a general power was in effect an estate that would pass under the donee's will. Dollar Sav. \& Trust Co. v. First Nat'l Bank, 32 Ohio Misc. 81, 285 N.E.2d 768 (C.P. 1972). If Ohio im fact follows this approach, it will produce the same result as the Massachusetts rule, although the basis of decision will be different.

195. The court in Emery v. Haven, 67 N.H. 503, 35 A. 940 (1894), held that a residuary clause exercised a general power and that extrinsic evidence was not admissible to show that the testator did not intend to exercise the power. The court cited Massachusetts cases and the English statute.

The court said that the testator had

[a]s complete and absolute testamentary power over the property as she had over any property that she owned. Such use, power, and provision in respect to descent would impress one unfamiliar with the technical rules of law as amounting to practical ownership. ... There is nothing in the language of the will tending to show that the testatrix did not intend to execute the power, except the absence of terins specifically referring to the power or the property to which it related.

Id. at 505,35 A. at 941 .

196. In Faulkner v. Faulkner, 93 N.H. 451,44 A.2d 429 (1945), the court characterized Emery as having denounced arbitrary rules of construction, and in effect overruled Emery, holding that the residuary clause did not exercise the power because there was no other evidence of any mtent to exercise it.

197. MASS. Gen. LAws ANN. ch. 191, \& 1A (West Cum. Supp. 1978-79), enacted Stat. 1976, ch. $515, \S 4$, effective January 1, 1978, provides:

[T] he following rules of construction shall apply to the provisions of a will:

4. No general residuary clause in a will and no will making general disposition of all of the testator's property shall exercise a power of appoimtment created by another instrument which does not specify a specific method of exercise unless reference is made to powers of appoimtment or there is some other indication of intention to exercise the power.

This statute was enacted as part of an omnibus reform bill prepared by the Boston Bar Association Probate Committee, which selected and adopted those parts of the Uniforn Probate Code considered "improvements." Probate Committee, Report, BosTon B.J., June 1975, at 27.

198. The presumption operating in the absence of any evidence that the donee either did or did not intend to exercise the power cannot by definition lead to the frustration of any apparent intent of the donee, because it operates only where there is no evidence of intent. However, when the presumption can be overcome only by very strong evidence or by language in the will itself, it 
more closely to the foundation laid by the three cases discussed above. ${ }^{199}$ The principal difference between these two lines is the quantity or strength of the evidence required to support an inference of imtention to exercise a power.

The inore conservative line is represented by DiSesa v. Hickey, ${ }^{200}$ decided by the Supreme Court of Errors of Connecticut in 1971. The testator created an inter vivos trust in 1962, reserving both a power to withdraw the principal at any time and a general testanentary power of appointment. In default of appointinent, the trust assets passed to his intestate takers. Under the Connecticut statute his wife was the sole intestate taker. His will, executed in 1966, made no inention of the power. It gave one-half of the residue of his estate to his wife ${ }^{201}$ and from the other one-half gave legacies totalling $\$ 50,000$ to various relatives and to a scholarship fund. The balance went to a mece. ${ }^{202}$ From the execution of the donee's will until his death ten inonths later, the value of the trust assets ranged between $\$ 650,000$ and $\$ 700,000$, and the value of his probate estate ranged between $\$ 25,000$ and $\$ 28,000$. The court held that the power was not exercised.

The standard articulated by the court regarding the strength of the evidence required to support an inference of intent to exercise was drawn from Blagge $v$. Miles: ${ }^{203}$ the intention must be "so clearly demonstrated by words or acts . . . that the transaction is not fairly susceptible of any other interpretation." 204 The court refused to hold that the donee's will exercised the power, even though there was sub-

immediately raises the possibihity of frustrating the donee's intent because the presumption cannot reflect what all donees would in fact intend.

199. See text accompanying notes $165-85$ supra.

200. 160 Conn. 250,278 A.2d 785 (1971).

201. She was a second spouse, his first wife having died in 1959. The trust was created just before their marriage in 1962. His will was made in 1966. Id. at 254, 278 A.2d at 787.

202. The will was drawn by DiSesa, the testator's associate since 1931 , who was also named as executor. Pertinent provisions of the will include the following:

I direct that my friend and associate of long standing, my attorney and executor . . . shall receive a total fee as iny attorney and executor for administering iny estate, an amount equal to fifteen percent (15\%) of the gross inventory of iny estate. [After giving jewelry and his automobile to his wife, the will continued]. . . [a]ll of the remainder of my estate, both real and personal, to iny said executor, to be distributed nevertheless by him as such executor as follows": (a) one-half to Mrs. Hickey; (b) $\$ 5,000$ to a nephew, Harold Hickey; (c) $\$ 10,000$ to a nephew, Marvin N. Hickey; (d) $\$ 10,000$ to a niece, Joan; and (e) $\$ 25,000$ to establish a scholarship fund with The Stamford Scholarship Foundation. ... "All the rest and residue of iny estate, of every kind and description not otherwise disposed of herein, I give, devise and bequeath to iny niece, Marian Harrell ... daughter of iny said late sister Jessie Standish, to be hers absolutely.

Id. at $254,278 \mathrm{~A} .2 \mathrm{~d}$ at 788 .

203. 3 F. Cas. 559 (C.C.D. Mass. 1841) (No. 1,479).

204. 160 Conn. at 250,278 A.2d at 790 (quoting Morgan Guar. Trust Co. v. Huntington, 149 Conn. 331, 344-45, 179 A.2d 604, 612 (1962)). 
stantial evidence from which such an inference of intent could have been drawn. The amount of the legacies alone required about twice the assets that were available in the probate estate. In addition, the will exhibited an intent to benefit the testator's meces and nephews as well as his wife. The result of holding the power unexercised was that the niece named to take the residue took nothing, and the wife, a late-imlife spouse, took everything. ${ }^{205}$

The court reasoned that the testator's will might fairly be susceptible of the interpretation that he did not intend to exercise the power because he was a lawyer, because his will had been drawn by his lawyer of many years, ${ }^{206}$ and because he could have made his probate estate adequate to cover the legacies by exercising his power to withdraw the corpus from the trust. The approach of the court in this case seems like that of the English court in the period immediately prior to $1830,{ }^{207}$ when no inference of intent to exercise the power would be drawn from an evident disparity between the size of the testator's estate and the amount of his legacies. The result, too, seems like the result of the English cases: frustration of an apparent intent to exercise the power. ${ }^{208}$

\section{The court stated:}

We have exainined with care the court's finding of fact and are unable to agree that it supports the court's conclusion that the will exercised the power of appointinent. As already noted, the will made no mention of the trust, the assets of the trust or the power of appointunent. Applying the further test as stated in Morgan Guaranty Trust Co. v. Huntington... we are unable to conclude that despite this omission the intention to exercise the power was "manifest" or "so clearly demonstrated by words or acts . . . that the transaction is not fairly susceptible of any other interpretation." An intention is "manifest" when it is "capable of being readily and instantly perceived by the senses"; "capable of being easily understood or recognized at once by the mind"; "obvious." . . . [A] fact is manifest when it appears upon the face of a record or is "readily apparent from an examination of authoritative sources of information, but not those the truth of which ... [has] to be determined by the weighing of evidence, or the credibility of witnesses, or the balancing of facts and circumstances or by processes of inference or deduction."

160 Conn. at 259-60, 278 A.2d at 790-91.

206. The court stated that the testator inust have known the Connecticut law. However, it is difficult to believe that either of these long-time practitioners would have left the question of exercise to implication or inference. The omission seeins inost hikely due to oversight. However, even if dehberate, it is difficult to draw a clear inference as to intent from the omission. Lawyers unfortunately, but perhaps not surprisingly, are not always fanriliar with the law on exercise of powers of appointment, as is made all too clear by the cases discussed herein. In a recent case from the state of Washington, a lawyer was held entitled to a fee three times greater than standard because he had discovered that under Massachusetts law the residuary clause of the decedent's will exercised a power created by a trust whose situs was there! In re Estate of Coffin, 7 Wash. App. 256, 499 P.2d 223 (1972).

207. See, e.g., Jones v. Curry, 36 Eng. Rep. 300 (M.R. 1818). This case is discussed in text accoinpanying notes $92-94$ supra.

208. The testator's will does not make sense unless it exercises the power. Quite apart from the fee given to the executor ( $15 \%$ of the inventory value), the legacies to ineces and nephews and the scholarship fund cannot be given effect. Although the testator deinonstrated a clear intent to 
The other line of modern American authority, the liberal line, ${ }^{209}$ is fairly represented by the New Jersey Supreme Court decision in Bank of New York v. Black. ${ }^{210}$ In this case, the donee held a general testamentary power created by her husband's will. The husband had given two-thirds of his estate to his children by a former marriage and the remaining third in trust for his wife for life, with power to appoint the takers of the corpus by her will. The wife died domiciled in Virgimia, which had a statute patterned after section 27 of the Enghish Wills Act of $1837 . .^{211} \mathrm{Her}$ will, not mentioning the power, left all her property to her daughter. Exercise of the power was governed by New Jersey law, the state of the donor's domicile. ${ }^{212}$

The standard the court articulated concerning the strength of the evidence required to support an inference of intention is quite different from that of Blagge v. Miles:.213

We do not think it is necessary for the appellant to present so forceful and compelling a case that it is impossible to form a rational supposition contrary to her contention. The object of our investigation is to determine the probable intent of the testatrix by a preponderance of the evidence and to carry it out in accordance with her wishes even though they be imperfectly expressed. . . . [W] put ourselves in her position insofar as possible, endeavoring to accomplish what she would have done could she have envisioned the present inquiry. Certainties are seldom attainable in this realm, and probabilities should customarily be sufficient. ${ }^{214}$

The court then considered evidence that the will was drawn by a Virginia lawyer who believed that the residuary clause would exercise the power, that the donee enjoyed a close relationship with her daughter, who was not wealthy, and that the amount of her property aside from the property subject to the power was not substantial. The court concluded that the donee had manifested an intent to exercise the

benefit his nieces and nephews to almost the same extent as his second spouse, the court, by finding that the will did not exercise the power, passed virtually all his property to the spouse (as his intestate taker under the trust) and almost nothing to the nieces and nephews-if indeed anything would be left at all of the probate assets after payment of administration expenses.

209. This line of authority is most fully developed in Illinois. See Rettig v. Zander, 364 Ill. 112, 4 N.E.2d 30 (1936); Illmois State Trust Co. v. Southern Ill. Nat'l Bank, 29 Ill. App. 3d 1, 329 N.E.2d 805 (1975); Northem Trust Co. v. Moscatelk, 54 Ill. App. 2d 316, 203 N.E.2d 447 (1964); Northern Trust Co. v. Cudahy, 339 Ill. App. 603, 91 N.E.2d 607 (1950).

210. 26 N.J. 276, 139 A.2d 393 (1958). This case should be contrasted with In re Deane's Will, 4 N.Y.2d 326, 151 N.E.2d 184, 175 N.Y.S.2d 21 (1958), discussed in text accompanying notes 13644 supra. The cases were decided in the same year and present quite similar fact patterns.

211. VA. CODE § 64.1-67 (1973).

212. 26 N.J. at 281,139 A.2d at 395 . The parties agreed on this point, in accord with the majority position in the United States. See text accompanymg note 35 supra.

213. 3 F. Cas. 559 (C.C.D. Mass. 1841) (No. 1,479).

214. 26 N.J. at $286-87,139$ A.2d at 398 (einphasis added). 
power. $^{215}$

American common law on the exercise of powers by imphication avoided the major trap laid by the Enghish courts and left im place by the reform statutes of the 1830s. By focusing on the need to carry out the donee's imtent, rather than on mamtaining a strict and technical view of the meaning of the donee's language, American courts were able to follow modern trends im imterpretation of wills and to look to evidence of the circumstances surrounding the will in ascertaining the donee's intent. $^{216}$ They were also able to adopt a more flexible standard for determining when it is proper to infer that the donee imtended to exercise the power. American common law authority, however, split over two particulars: the standard to be applied im determining whetler the evidence will support an inference of intent to exercise, and the admissibility of the testator's declarations of intent to exercise the power. ${ }^{217}$

215. Id. at $282,294,139$ A.2d at 396,402 . There was a strongly worded dissent that protested that the donee's will was being remade by parole, and that the donor was an eminent lawyer, who would, or at least could, have provided a gift in default of appointment to the donee's daughter (her residuary taker) if he had intended to do so.

Earlier New Jersey cases fall into the conservative camp. The opinion in Bank of New York does not really attempt to discuss the earlier cases: Pennsylvania Co. For Ins. on Lives \& Granting Annuities v. Morrell, 108 N.J. Eq. 188, 154 A. 416 (1931) ("my estate" creates no ambiguity when used by the holder of a power); Farnum v. Pennsylvania Co. For Ins. on Lives \& Granting Annuities, 87 N.J. Eq. 108, 99 A. 145 (1916), affd, 87 N.J. Eq. 652, 101 A. 1053 (1917).

The Farnum case is interesting for its treatment of the proffered testimony of the scrivener that he dropped the language expressly exercising the power from a former version of the donee's will because it was surplusage under the law of the donee's domicile:

No reflection upon his veracity is meant, but it is imcomprehensible why he should lave gambled with his client's interest and wly he should have banked upon his very meager knowledge of the laws of a foreign state [Pennsylvania] to accomplish that which a few plain words would have expressed.

87 N.J. Eq. at 115,99 A. at 148 .

216. 4 BOwE \& PARKER, supra note $24, \S 30.2$. The following excerpt from Justice Story's opinion in Blagge v. Miles, 3 F. Cas. at 566, describes the nodernization:

There was a long struggle in Westminister hall upon the point, whether in wills, the intention of the testator, as gathered ex visceribus testamenti, was to be followed in the interpretation of devises, or whether the technical construction of law, given to certam phrases, was to prevail over the intention. That struggle, at least, since the decision in Perrin v. Blake . . . seems to have terminated. It is now admitted to be established, as the general rule, that the intention of the testator is the polestar to direct the court in the interpretation of wills, and that technical words and set phrases are controlled by, and do not control, that intention, when clearly expressed or positively ascertamed. The consequence is, that decisions upon particular wills are of far less consequence now, than they formerly were supposed to be; unless, indeed, where the leading provisions are almost identical, and the facts substantially alike. They now furmsh, not so much authorities, as Id. analogies, by which to interpret the words of wills in new cases.

217. The majority rule is that direct declarations of the testator's intent are not admissible except in the case of an equivocation. Some states, however, have adopted the position that such statements should be admissible wherever relevant to any question of interpretation of the will. See note 24 supra. 
The more conservative American courts have retamed the standard articulated by Justice Story in Blagge, that the evidence of intent to exercise must be convincing and "not fairly susceptible of any other interpretation."218 The inore liberal American courts now require only that the evidence supporting an inference of an intent to exercise the power preponderate, that it be inore likely than not that the donee intended to exercise the power. Although the data are too limited to draw a conclusion, there is soine basis for stating that courts following the conservative standard exclude evidence of the testator's declarations of intent, while those following the liberal standard are willing to admit such declarations. ${ }^{219}$ All American courts applying the common law, however, do adınit extrinsic evidence of the circumstances surrounding execution of the donee's will, except for direct declarations of intent, and consequently are consistently able to reach results superior to those reached by courts forced to apply statutes that exclude extrinsic evidence.

The jurisdictions that do not admit a testator's direct declarations of imtent base their decisions on their fears of fraud and perjury and their concern that such evidence would undermine the statutory requirements of written wills. Hyatt v. Jurczyk, 368 F.2d 546 (1st Cir. 1966); In re Estate of White, 9 Cal. App. 3d 194, 87 Cal. Rptr. 881 (1970); McFarland v. Chase Manhattan Bank, N.A., 32 Conn. Supp. 20, 337 A.2d 1 (1973); Ziehl v. Maine Nat'l Bank, 383 A.2d 1364 (Me. 1978); In re Estate of Kelly, 473 Pa. 48, 373 A.2d 744 (1977); Green v. Lanier, 61 Tenn. App. 487, 456 S.W.2d 345 (1970); 4 BowE \& PARKer, supra note 24, \$ 32.9. Some jurisdictions that exclude direct declarations as a general rule have created exceptions in the following situations: when the evidence is offered to show the testator's understanding of certain words reasonably susceptible of more than one interpretation, In re Estate of Flint, 25 Cal. App. 3d 945, 102 Cal. Rptr. 345 (1972); to show his "state of inind," In re Estate of White, 9 Cal. App. 3d 194, 87 Cal. Rptr. 881 (1970); or to show his feelings towards and relations with other people, McKelvy v. Terry, 370 Mass. 328, 346 N.E.2d 912 (1976). Massachusetts, in 1976, still followed the rule that a residuary clause exercised a power in the absence of evidence to the contrary in the will. See notes 104-99 supra and accompanying text. Thus, admission of such evidence only served to confirm the result the court would have reached without any evidence at all.

218. 3 F. Cas. at 566.

219. Compare Northern Trust Co. v. Moscatelli, 54 Ill. App. 2d 316, 203 N.E.2d 447 (1964) and Bank of N.Y. v. Black, 26 N.J. 276, 139 A.2d 393 (1958) with Farnum v. Pennsylvania Co. For Ins. on Lives \& Granting Annuities, 87 N.J. Eq. 108, 99 A. 145 (1916), affd, 87 N.J. Eq. 652, 101 A. 1053 (1917). But see Hartford-Connecticut Trust Co. v. Thayer, 105 Conn. 57, 134 A. 155 (1926). On the adinission of scrivener testimony generally, see 4 BOWE \& PARKER, supra note 24, \$ 32.9. It may be that scrivener testimony is admissible to show the state of the donee/testator's knowledge of the existence of the power, as im Hartford-Connecticut Trust, but is not admissible if it is designed to demonstrate directly that the testator did or did not intend to execute the power as in Farnum. See also Estate of Carter v. Church Divinity School of the Pacific, 47 Cal. 2d 200, 302 P. 301 (1956); Morffew v. San Francisco \& S.R.R., 107 Cal. 587, 40 P. 810 (1895); In re Deane's Will, 4 N.Y.2d 326, 151 N.E.2d 184, 175 N.Y.S.2d 21 (1958). 


\section{Modern United States Statutes}

Since 1948, the year the marital deduction was enacted, ${ }^{220}$ estate plans of unarried people have commonly included a marital deduction trust. ${ }^{221}$ This kind of trust, designed to secure the marital deduction without transferring property outright to the surviving spouse, ${ }^{222}$ gives the surviving spouse a life estate and a general testamentary power of appointment over the remainder ${ }^{223}$ The primary purpose of creating the power is to qualify the property for the marital deduction, not to provide the surviving spouse with the power to dispose of the property by her will. In such estate plans the donor imtends that the clause in default of appointment control devolution of the property, and that the donee will refrain from exercising the power. Statutes providing that the residuary clause or other general disposition in the donee's will exercises a power can wreak liavoc on these estate plans. Over the past two decades, there lias been substantial pressure to repeal or severely curtail the operation of statutes based on the 1830 seforms $^{224}$ and to enact statutes designed to prevent adoption of any presumption favoring exercise of powers of appointınent.

220. Revenue Act of 1948, Pub. L. No. 80-471, § 361, 62 Stat. 110 (current version at I.R.C. $\S 2056$, as amended by Tax Reform Act of 1976, Pub. L. No. 94-455, 90 Stat. 1520).

221. CASNer, supra note 1, at 783-874; TrachtMan, supra note 1, at 201-11; Allen, Use of Trusts and Powers of Appointment in Estate Planning, 21 ARK. L. REv. 15 (1967); Craven, Powers of Appointment Act of 1951, 65 HARv. L. Rev. 55 (1951); Halbach, supra note 1; Rusoff, Powers of Appointment and Estate Planning, 10 J. FAM. L. 443, 457 (1971).

222. The marital deduction postpones taxation of property belonging to the first spouse until the death of the second spouse. This postponement is accomplished by requiring that the property qualifying for the deduction be such that, unless disposed of during life, it will be taxable in the estate of the surviving spouse. An outright transfer of a fee interest will of course qualify, while a simple life estate will not. Treas. Reg. \& 20.2056(a)-2 (1958) defines "deductible interests," and Treas. Reg. $\S 20.2056(\mathrm{~b})-1$ (1958) defines "terminable interests" that are not deductible.

223. If the surviving spouse is entitled to all the income, payable at least annually, for life, and lias a power to appoint the property either to herself or to her estate, the property qualifies for the marital deduction under I.R.C. $\$ 2056(b)(5)$. Under I.R.C. $\S 2041$ (b)(1) such a power is defined as a general power of appointment, and the property subject to such a power is includible in the gross estate of the donee under I.R.C. \& 2041(a).

224. See Uniform Probate Code $\$ 2-610$ comment. Although there seems to be a perception that general powers are used almost exclusively in marital deduction trusts, this is not necessarily true. They are also commonly used in inter vivos trusts not created to acquire any death-tax advantages. Although the statutes have created some problems for powers in sucl trusts, see California Trust Co. v. Ott, 59 Cal. App. 2d 715, 140 P.2d 79 (1943), the source of pressure for change seems to be the marital deduction trust.

Another factor creating pressure for change is that exercise of a power triggers includibility of the appointive assets in the donee's estate for pre-1942 powers under I.R.C. \& 2041(b)(3) and for certain types of powers under state inheritance tax statutes. See Rabin, supra note 126, at 4-7, for a complete discussion of state inheritance tax treatment of powers. However, pre-1942 powers liave largely been cut down by release. See, e.g., Beals v. State St. Bank \& Trust Co., 367 Mass. 318,326 N.E.2d 896 (1975). In addition, state inheritance taxes in the usual case do not involve enough inoney to produce pressure for this kind of change. 
Since 1965 nineteen states have enacted statutes that address the question whether a general disposition or residuary clause in the donee's will exercises a power of appointinent. ${ }^{225}$ All of these statutes, except those of New York and California, adopt the basic premise of the coinmon law, that a general disposition or residuary clause, without inore, does not exercise a power. These statutes fall imto three groups: those based on the Uniforn1 Probate Code, those tailor-made to reverse statutes based on the 1830 nodels, and those of New York and Cahfornia.

\section{A. Statutes Based on the Uniform Probate Code.}

The Uniform Probate Code (UPC) has now been adopted in twelve states, ${ }^{226}$ and an additional two states have enacted identical statutes on the exercise of powers of appointment. ${ }^{227}$ In several states these provisions have been enacted to eliminate prior statutes modeled on the Enghish or New York statutes of the 1830s. ${ }^{228}$

UPC section 2-610 states:

A general residuary clause in a will, or a will making general disposition of all of the testator's property, does not exercise a power of appointment held by the testator unless specific reference is made to the power or there is some other indication of intention to include the property subject to the power. 229 .

This section enacts the common law of execution of powers as developed in the United States ${ }^{230}$ and specifically contemplates that extrimsic evidence inay be introduced to show the donee's intent.

The Comment to this section of the UPC, however, is confusing. It states that

the intent to exercise the power is effective if it is "mdicated by the will." This wording permits a Court to find the manifest intent if the

225. Alaska, Arizona, California, Colorado, Florida, Hawaii, Idaho, Maryland, Massachusetts, Michigan, Minnesota, Montana, Nebraska, New Mexico, New York, North Dakota, Oregon, Utah, and Wisconsin. The Michigan, Minnesota, Montana, North Dakota, Utah, and Wisconsin statutes were designed to reverse the presumption of their former statutes that were patterned after the New York statute. The Maryland and Massachusetts statutes reversed the presunption of a statute and a judicial rule of construction patterned on the English statute. Alaska, Arizona, Colorado, Florida, Hawaii, Idaho, Nebraska, New Mexico, and Oregon had no prior statute. See notes 29-31 \& 33 supra for citations.

226. These twelve states are Alaska, Arizona, Colorado, Florida, Hawaii, Idaho, Minnesota, Montana, Nebraska, New Mexico, North Dakota, and Utah. 8 UNIForm LAws ANNotated 83 (Cum. Supp. 1979).

227. See Mass. Gen. Laws Ann. ch. 191, § IA (West Cum. Supp. 1978-79); Or. Rev. Stat. $\S 112.410$ (1975).

228. See Minn. Stat. Ann. § 524.2-610 (West 1978); Mont. Rev. Codes ANn. § 91A-2-610 (1975); N.D. CENT. CODE § 30.1-09-10 (1976); UTAH CODE ANN. § 75-2-610 (1977).

229. 8 UNIFORM LAWS ANNOTATED 361 (1972) (einphasis added).

230. See notes 165-219 supra and accompanying text. 
language of the will interpreted in light of all the surrounding circumstances shows that the donee intended an exercise . . . . In other words, the modern liberal rule on interpretation of the donee's will would be available. ${ }^{231}$

This possible inconsistency can be explained by consulting the third working draft of the UPC. Section 2-608 of that draft provided: "A will, whether or not it contains a residuary clause, does not exercise a power of appointment held by the testator unless an intent to exercise the power is indicated by the will."232 The Comment to this section of the draft is the saine one that appears in the final version of section 2610. The change in the statute makes it clear that the final version is intended to permit courts to consult extrinsic evidence for intent to exercise. The quoted portion of the Comment was apparently mcluded in the final version inadvertently. ${ }^{233}$

As a result of the failure to draft a new Comment to section 2-610, the Code offers no guidance as to whether the liberal or the conservative line of American authority should be followed on the standard to be applied to the evidence. Under the section as enacted, a court presuinably would be free to adopt even the Enghish standard from $A n$ drews v. Emmot, ${ }^{234}$ as well as those from Blagge v. Miles ${ }^{235}$ or Bank of New York v. Black. ${ }^{236}$ As illustrated in Parts II and V above, the standard a court chooses to apply may determine what kinds of evidence it will admit ${ }^{237}$ as well as the result it will ultimately reach. The statutes based on this uniforin provision will avoid the danger of inadvertent exercise, but they will not provide the means to achieve consistent interpretation of donees' wills throughout the United States unless further action is taken to specify the applicable standard.

\section{B. Tailor-Made Statutes Restoring Common Law Principles.}

Statutes individually designed to reverse the presumption of prior statutes have been enacted in Maryland, Michigan, and Wisconsin. ${ }^{238}$ The Maryland statute, enacted to replace its Enghish-based predeces-

231. Uniform Probate CODE \$ 2-610 comment. See text accompanying note 56 supra for the modern liberal rule.

232. National Conference of Commissioners on Uniform State laws, Third Working Draft Uniform Probate Code 106 (Nov. 1967) (einphasis added).

233. The author confirmed this conclusion by telephone conversation with Richard V. Wellinan, Chief Reporter for the Uniform Probate Code, on October 19, 1978.

234. 29 Eng. Rep. 162, 165 (Ch. 1788).

235. 3 F. Cas. 559 (C.C.D. Mass. 1841) (No. 1,479).

236. 26 N.J. 276, 139 A.2d 393 (1958).

237. See discussion at note 219 supra and accoinpanying text.

238. Citations are set forth in note 31 supra. 
sor, ${ }^{239}$ provides that a residuary clause exercises a power of appointment only if an intent to exercise "is expressly mdicated in the will; or the instrument creating the power fails to provide for disposition of the subject matter upon its non-exercise."240

This language retains the requirement of the previous statute that an intention contrary to the statutory presumption must appear in the will. Thus, the new statute does no more than change the presumption; under both the old and new statutes, the court is prevented from considering evidence extrinsic to the will to ascertain the donee's imtent. ${ }^{241}$

The substantially identical Michigan and Wisconsin statutes replace earlier statutes based on the New York model. ${ }^{242}$ The Michigan version provides:

Unless otherwise provided in the creating instrunent, an instrument manifests an intent to exercise the power if the instrument purports to transfer an interest in the appointive property which the donee would have no power to transfer except by virtue of the power, even though the power is not recited or referred to in the instrument, or if the instrument either expressly or by necessary implication froin its wording interpreted in the light of the circumstances surrounding its drafting and execution, mamfests an intent to exercise the power $\ldots$. [I]f there is a general power exercisable by will with no express gift in default in the creating instrument, a residuary clause or other general language in the donee's will purporting to dispose of all the donee's estate or property operates to exercise the power but in all other cases such a clause or language does not im itself manifest an intent to exercise a . . . power exercisable by will . . . . ${ }^{243}$

Two passages of the statute are critical: first, "if the instrument either expressly or by necessary imphication from its wording"; and second, "interpreted in the light of the circumstances surrounding its drafting

239. MD. ANN. CODE art. 93, $\$ 359$ (1957) (originally enacted in 1888) (repealed MD. EsT. \& Trusts CoDe ANN. \& 4-407 (1974)) provided:

Every devise and bequest purporting to be of all real and personal property belonging to the testator shall be construed to include also all property over which he has a general power of appointment, unless the contrary intention shall appear in the will or codicil containing such devise or bequest.

240. MD. Est. \& Trusts CODE ANN. \$ 4-407 (1974).

241. Leidy Chems. Foundation, Inc. v. First Nat'l Bank, 276 Md. 689, 351 A.2d 129 (1976), was decided under the new statute. The court held that it reinstated the law as it existed prior to 1888. "The intention to execute a power of appointment by will inust appear by a reference in the will to the power, or the subject of it, or from the fact that the will would be inoperative without the aid of the power." Id. at 693, 351 A.2d at 131 (quoting Balls v. Dampman, 69 Md. 390, 393, 16 A. 16, 17 (1889) (quoting Mory v. Michael, $18 \mathrm{Md}$. 227, 241 (1862))). The court held there was no exercise here even though it quite clearly appeared, froin comparing the takers in default with the takcr under the donee's will, that the donee had intended to exercise the power.

242. 5 American Law of Property \& 23.40, at 563-64 \& n.15.

243. Mich. Comp. Laws AnN. $\S 556.114$ (Cum. Supp. 1979-80) (Mich. Stat. AnN. $\$ 26.155$ (104) (Callaghan 1974)). 
and execution, inanifests an intent to exercise the power." The language of the first passage is the same as that of the New York model, which was held absolutely to preclude consideration of extrinsic evidence. 244 If "necessary implication" demands that no other conclusion be possible, as the court required in Andrews, ${ }^{245}$ then the language of the second passage may mean no more than that the court may consider evidence that the donee had only a power over property disposed of by specific devise or bequest in his will. Thus, the statute would adopt the position of the Enghish courts prior to the statute of $1837 . .^{246}$ However, the second passage could also be imterpreted to allow a more liberal standard like that of Blagge v. Miles, ${ }^{247}$ and to permit the court to consider evidence of the testator's assets and relations with the takers under his will ${ }^{248}$ and the takers in default im determining whether he intended to exercise the power.

In interpreting this statute, the Michigan court in Hund v. $H_{\text {Holmes }}{ }^{249}$ apparently adopted the view of the English cases prior to 1837. The court held that the statute prohibited the use of extrinsic evidence to show that the donee mtended the residuary clause of his will to exercise a power. The court reasoned:

This statute restricts the use of extrinsic evidence to circumstances surrounding the drafting and execution of the instrument and prohibits the introduction of such evidence unless it explains or clarifies soine "wording" of the instrument. It also declares that when the donor has provided for an express gift in default, the language of a residuary clause does not manifest the intent to exercise a power. ${ }^{250}$

The appellee in Hund tried to support the trial court's findimg of an intent to exercise with evidence of the "testatrix's selection of an attor-

244. In re Deane's Will, 4 N.Y.2d 326, 151 N.E.2d 184, 175 N.Y.S.2d 21 (1958). Of course, the result was the reverse: application of the statute resulted in exercise.

245. See text accompanying note 65 supra.

246. See text accompanying notes 102-03 supra.

247. 3 F. Cas. 559 (C.C.D. Mass. 1841) (No. 1,479). See note 166 supra, and text accompanying notes 166-69 supra.

248. This phrase, "interpreted in light of the circumstances surrounding," is defined in Rettig v. Zander, 364 Ill. 112, 4 N.E.2d 30 (1936): "The circumstances under which the will was written properly include the nature, extent and condition of the testator's property, the relations between the testator and his family and his relations to the beneficiaries named in his will." Id. at 120-21, 4 N.E.2d at 34. See also the discussion in note 216 supra.

249. 395 Mich. 188, 235 N.W.2d 331 (1975).

250. Id. at 197,235 N.W.2d at 335 . The court also stated:

Construction often requires an examination of the language of a will in light of extrinsic facts and circumstances surrounding a testator at the time he executed his will. When admitting extrinsic evidence, it is imperative that courts remember they may not venture beyond construing language in the will in order to discover imtent. The use of extrinsic evidence of facts and circumstances is limited to interpreting the words and phrases in the will.

Id. at 196-97, 235 N.W.2d at 334 
ney, her choice of beneficiaries and distribution of estate, the prior law and the novelty of marital trusts in 1955."251 The Michigan court held that these proofs could not be used to interpret the wording of the will. ${ }^{252}$ Accordingly, it was unable to find a "necessary implication"253 of intent to exercise from "the 'wording' of a simple, garden variety residuary clause."254 To hold otherwise, the court decided, would render ineaningless the "but in all other cases" portion of the final sentence of the statute. ${ }^{255}$

Despite the court's citation of American authority, ${ }^{256}$ it is clear that it has essentially adopted the position of the English courts: words like "iny estate," "my property," or "the rest, residue and remainder of my estate" do not call for extrinsic evidence to explain that they mean property that does not belong to the testator, if it is possible to give the words their ordinary meaning. The court, however, is simply wrong in reasoning that the "but in all other cases" portion of the final sentence requires this result. That sentence could as well inean "in all cases where there is a default clause and where the donee has not manifested an intention to exercise the power by the words of his will imterpreted in the hight of his assets and relationships at the date of the will." Had this been the interpretation, the court would have reached the opposite result and would have found froin the extrinsic evidence that the donee had intended to exercise the power. ${ }^{257}$.

If Wisconsin follows the Michigan interpretation of the statute, all three of these states-Maryland, Wisconsin, and Michigan-will have returned by statute to the common law as it existed in England in 1830. Courts will be prevented from looking beyond the will to any evidence of the donee's intent; courts will be forced to find that the donee did not exercise the power even though they are convinced he intended to do so. They have come full circle, and this state of the law will again produce the kinds of dissatisfaction that triggered the reforms of the 1830s. The only way to avoid this result is to amend the statutes to

251. Id. at 197,235 N.W.2d at 335.

252. Id. at $197-98,235$ N.W.2d at 335 .

253. Id. at 198, 235 N.W.2d at 335.

254. Id.

255. Id.

256. Id. at 194, 235 N.W.2d at 333. The court cited Blagge v. Miles, 3 F. Cas. 559 (C.C.D. Mass. 1841) (No. 1,479); Morgan Guar. Trust Co. v. Huntington, 149 Conn. 331, 179 A.2d 604 (1962); Republic Nat'l Bank v. Fredericks, 155 Tex. 79, 283 S.W.2d 39 (1955); and Annot., 15 A.L.R.3d 346 (1967).

257. Her will was drawn under the prior law by the lawyer who drew the donor's will. Her exercise would have resulted in half of their property going to his relatives and half to hers. The law was changed only three months before she died. See 395 Mich. at 199-203, 235 N.W.2d at 335-38 (Coleman, J., dissenting). 
permit consideration of extrinsic evidence of intent. ${ }^{258}$

\section{New York and California Statutes.}

New York and Califorina provide a sharp contrast to those states that have recently enacted statutes restoring the common law on exercise of powers by residuary clauses. Both states, in the process of making coinprehensive revisions and codifications of the law of powers of appoimtment, ${ }^{259}$ have re-enacted the substance of their prior statutes despite recommendations to the contrary. ${ }^{260}$ Although these two statutes contmue the basic presuinption that the donee intends to exercise a power by a residuary clause or other general disposition of property, they differ substantially in other respects.

The New York statute now provides that a power is effectively exercised when the donee "[l]eaves a will disposing of all of his property or all of his property of the kind covered by the power, unless the intention that the will is not to operate as an execution of the power appears expressly or by necessary implication."261

This statute is identical to the original New York statute of $1830^{262}$ in that it applies to any power, whether general or special, and the power will be exercised unless a contrary intention appears expressly or by necessary implication. This language is the saine as that of the earlier statute, which was held to preclude the admissibility of evidence extrinsic to the will. ${ }^{263}$ Thus, the new statute does not appear to have effected any substantive changes, and cases like those discussed im Part IV may be expected to contimue to arise.

In contrast to the New York statute, the California statute under-

258. Repeal of the statutes could of course achieve the same result.

259. Cal. Clv. Code $\S \S 1380.1-1392.1$ (West Cum. Supp. 1979); N.Y. Est., Powers \& Trusts Law $\$ \S 10-1.1$ to 10-8.1 (McKinney Cum. Supp. 1978-79).

260. Professor Richard R. Powell was the major architect of each statute. See Powell, Powers of Appointment in California, 19 Hastings L.J. 1281 (1968); Powell, The New Powers of Appointment Act, 103 TR. \& EST. 807 (1964). The earher article on the New York revisions does not mention the continuance of the prior statute on exercise except to say that the new statute "retains upwards of $\mathbf{3 0}$ of the provisions in the old statute which have proved their worth in use." Id. 809. However, in the study that he prepared for the California Law Revision Commission, Powell indicates that he questioned the wisdom of retaining this feature of the prior New York law. Powell, Consultant's Study 7, in California Law Revision Commission, Study \#69, Powers OF APPOINTMENT (1967) (available in the collection of the University of California, Davis, Law Library). The basis of Powell's objection to the 1830s statutes was that they created an "undesirable pitfall for the unwary." Powell, 19 HASTINGS L.J., supra at 1291.

261. N.Y. Est., Powers \& TRusts Law \& 10-6.1 (McKinney Cum. Supp. 1978-79) (emphasis added).

262. The statute is set forth in text accompanying note 106 supra.

263. In re Deane's Will, 4 N.Y.2d 326, 151 N.E.2d 184, 175 N.Y.S.2d 21 (1958). See text accompanying notes 136-44 supra for a discussion of the case. 


\section{took to change the prior law. ${ }^{264}$ The new statute reads as follows:}

264. The Tentative Recommendation Relating to Powers of Appointunent (issued June 1, 1968) by the California Law Revision Commission, accepted Professor Powell's recommendation. Section 1386.2 , id. 29 , provided:

A general power of appointment exercisable at the death of the donee is exercised by a residuary clause or other general language in the donee's will purporting to dispose of all of the donee's property of the kind covered by the power if: (a) The creating instrument does not provide for a gift in default and does not require that the donee make a specific reference to the power; and (b) The donee's will does not manifest an intent, either expressly or by necessary inference, not to exercise the power.

This section was patterned after the new Wisconsin statute, discussed in text accompanying notes 242-58 supra. Powell, Consultant's Study, supra note 260, at 18. This recommendation, however, was ultimately rejected by the Law Revision Commission because of the objection of Professor Edward H. Rabin. Letter from Edward H. Rabin to the California Law Revision Commission (June 21, 1968). With respect to the proposed section 1386.2, Rabin commented:

A fundamental change which I urge would alter paragraph (a) to read as follows: "(a) The creating instrument does not require that the donee make a specific reference to the power, and ...." This would basically merely modify Probate Code $\S 125$, whereas $\S 1386.2$ (a) as now proposed radically changes it. I have previously written on this matter as follows:

"To start, we may ask, "Why should not the donee attempt to exercise all powers which he may possess at the time of his death?" The testator-donee ordinarily wishes to benefit his legatees to the maximum extent of his ability. He wants to pass any property which lie can to his legatees. A failure to dispose of unknown or after-acquired appointive property is as unnatural as a failure to dispose of unknown or after-acquired owned property. Unless there are disadvantages to disposing of unknown appoimtive property which outweigh the donee's natural desire to benefit his legatees, the donee should attempt to exercise unknown powers.

51 CoRnell L.Q. 2 (1965))

As far as non-tax factors are concerned I believe that a rule which makes the residuary clause exercise all powers (in the absence of an expressed contrary intent by either the donor or the donee) will more often promote a just disposition than the contrary rule.

....

As far as tax factors are concerned . . . these have been given undue importance. Serious tax disadvantages inay result froin a thoughtless or inadvertent exercise only (1) when the power was created before October 22, 1942, and (2) it was a general power, and (3) the donor was not also the donee.

Id. Professor Rabin apparently gave no credence to the notion underlying the Unifornu Probate Code provision that consideration should be given to the likely intent of the donor of a marital deduction trust.

In contrast to Professor Rabin's position, the California Bankers Association Legislative Committee, Trust Division, in a draft transmitted to the Commission by letter dated August 21, 1968, had commented:

We believe the cliange to avoid inadvertent exercise of the powers is an excellent one. However, it might be noted that, in the rare situation where a power is exercised by a residuary clause under 1386.2 , and the power is a pre-1941 power, it would subject the property to U.S. Estate taxation. However, this has to be balanced against the disadvantage of a reversion.

Letter from the California Bankers Association Legislative Committee, Trust Division, to the Cal-

ifornia Law Revision Commission (Aug. 21, 1968). The Commission Staffs response was:

Professor Rabin's suggested revision might be inore acceptable if the word "will" were deleted from subdivision (b) so that the donee's actual intent, as in Estate of Carter, not to exercise the power could be shown, even though there is nothing in his will one way or the other.

The Commission has given considerable thought to this change. It meets the approval of the Bankers Legislative Committee but not Professor Rabin. The question is strictly one of policy.

First Supplement to Memorandum 68-77, at 14 (Sept. 12, 1968). 
A general power of appointment exercisable at the death of the donee is exercised by a residuary clause or other general language in the donee's will purporting to dispose of the property of the kind covered by the power unless ... [t] the donee manifests an intent, either expressly or by necessary inference, not to so exercise the power. ${ }^{265}$

One change effected by the statute is apparent: it applies only to general powers, whereas the prior statute applied to all powers. ${ }^{266}$ The Report of the California Law Revision Commission contains no recognition that the statute changes the prior law and no explanation for the change. ${ }^{267}$

The Commission's report states that the new statute was designed to change the holding of Estate of Carter ${ }^{268}$ that, under the prior law, extrinsic evidence of the donee's intent not to exercise the power was niadmissible. ${ }^{269}$ However, the language chosen, requiring the donee to

The commission subsequently reversed its position. Minutes of September 19-21, 1968 . Memorandum 68-99, at 2 (Oct. 9, 1968) states:

Section 1386.2 was revised to reflect the Commission's decision that a residuary clause should exercise a general power of appointment unless the creating instrument requires a specific reference to either the power or the creating instrument or the donee manifests an intent not to so exercise the power. The Comment, of course, was redrafted in accordance with this change.

These records were kindly made available to the author by John $\mathrm{H}$. DeMoully, Executive Secretary of the California Law Revision Commission. A complete copy of the file on Study \#69, Powers of Appointment, is now held in the collection of the University of California, Davis, Law Library.

265. CAL. CIv. Code $\S 1386.2$ (West Cum. Supp. 1978) (emphasis added).

266. Prior to enactment of CAL. CIV. Code $\S$ 1386.2, Cal. Prob. Code $\S 125$ (West 1956) (current version at CAL. Prob. CODE $\S 125$ (West Cum. Supp. 1979)), provided:

A devise or bequest of all the testator's real or personal property, im express terms, or in any other terms denoting his intent to dispose of all his real or personal property, passes all the real or personal property which he was entitled to dispose of by will at the time of his death, including property embraced in a powcr to devise.

This statute applied to special as well as general powers. United Cal. Bank v. Bottler, $16 \mathrm{Cal}$. App. 3d 610, 94 Cal. Rptr. 227 (1971).

267. 9 California Law Revision Commission, Reports, Recommendations and StudIES 1968-69, at 301-52 (1969). The explanation for the cliange can be found in the history of the new section, 1386.2, detailed in note 264 supra. When Professor Rabin suggested returning to the rule of California Probate Code section 125, CAL. Prob. Code $\S 125$ (West 1956) (amended by 1969 Cal. Stats. ch. 155, \& 3), he did so by working with the language of Powell's draft, which was modeled on the Wisconsin section that provided for automatic exercise only where the power was general and the donor had named no taker in default. The theory underlying this statute was obviously that in sucl circumstances the donor had intended that the donee enjoy and use full dispositive power over the assets. It makes more sense, then, to pass them as if they belonged to the donee than to pass them to the residuary or intestate takers of the donor. It seems unlikely that Professor Rabin would have wanted to confine his presumption favoring exercise to general powers in view of his stated rationale for the presumption.

268. $47 \mathrm{Cal} .2 \mathrm{~d} \mathrm{200,} 302$ P.2d 301 (1956). This case is discussed in text accompanying notes 154-59 supra.

269. The Comment to $\S 1386.2$ provides:

This section modifies the rule stated in Probate Code Section 125. In Estate of Carter . . the Supreme Court interpreted that section to require a holding that a residuary clause, which did not mention a general testamentary power with gifts in default, 
manifest the contrary intent either "expressly or by necessary inference," is virtually identical to the language of the New York statute, ${ }^{270}$ which has consistently been held to require that the contrary intent be expressed in the donee's will. ${ }^{271}$ Since the Comment of the Law Revision Commission clearly states that the intention was to change the rule of Estate of Carter, ${ }^{272}$ California courts should hold that the statute allows consideration of extrinsic evidence of the donee's intent. If they do, the courts will no longer reach the absurd results produced by the earlier statute. If the California courts are also willing to adopt the preponderance standard of the New Jersey and Illinois courts, ${ }^{273}$ they should be able to carry out the donee's intent consistently when there is evidence froin which it can be ascertained. The Cahfornia courts would reach results different from those in New Jersey or Illinois only when there is no evidence of the donee's intent. In such a case, California would hold a general power exercised by the residuary clause; New Jersey and Illinois would not. ${ }^{274}$ The relative inerits of these two positions are considered in the next section.

\section{CONCLUSIONS}

When the donee of a power of appomtment dies testate, and his will disposes of property similar to the appointive property but makes no mention of the power, exercise of the power may depend on which state's law governs the interpretation of the donee's will. That state is usually the state whose law governs the interpretation of the instrument that created the power, which may be a state other than that of the donee's donicile or that where the donee's will was drafted or exe-

exercised the power despite the donee's specific intent not to exercise the power. . . . Under this section, the donee's intent not to exercise the power may be manifested, either expressly or by necessary inference, by the terms of his will, contrary to Estate of Carter, by evidence apart from the will. This section thus ehiminates the trap for the unwary that defeated the donee's clearly provable intent in Estate of Carter.

CAL. CIv. Code § 1386.2 comment (West Cum. Supp. 1979).

270. The difference between "implication" and "inference" in these two statutes seems unlikely to have any particular significance. Strictly speaking, the New York usage is correct; California's is not. A writer "implies"; a reader "infers." In each statute the question is whether the donee has manifested his intent. Whether the intent "appears by" (New York) or is "manifest[ed] . . . by" (California), the reference seems to be to the writer rather than to the reader. Thus, the donee's intent should appear or be manifested by the writer's implication rather than from the reader's inference.

271. See text accompanying note 263 supra.

272. $47 \mathrm{Cal} .2 \mathrm{~d} \mathrm{200,} 302 \mathrm{P} .2 \mathrm{~d} 301$ (1956). This case is discussed in text accompanying notes 154-59 supra.

273. See text accompanying note 214 supra for discussion of this standard.

274. Presumably California will treat special powers as governed by the common law, rather than by the statutory rnle. CAL. CIV. CODE $\S 1380.1$ (West Cum. Supp. 1979) provides that the common law of powers is the law of California except where modified by statute. 
cuted. Once the governing law has been determined, exercise of the power may depend on whether the donee's power is general or special, or on whether there is a clause in default of exercise in the instrument creating the power. Beyond these variables, exercise may also depend on whether the court will consider extrinsic evidence in determining the donee's intent, on what kinds of extrinsic evidence it will consider, and on the quantum of evidence it will require to reach a result contrary to its basic assumption as to the donee's imtent. In a number of states, where the law has changed im recent years, the result will also depend on the date of the donee's death.

To illustrate the complexity of these probleins, suppose a standard type of estate plan in which the wife's will creates a marital deduction trust and a residuary family trust. She gives the husband a general testamentary power over the remainder of the marital deduction trust and a special power to appoint the assets of the family trust annong her descendants and their spouses. The takers in default under both trusts are her descendants living at the husband's death, per stirpes. After the wife's deatl, the husband remarries, and at his death he is survived by the second wife, the two children of his first marriage, and a grandchild. His will says simply that he leaves one-fourth of all his property to the grandchild and three-fourths to the second wife. Does the will execute either or both powers, so that the second wife and grandchild take to the exclusion of the children? In answering this question, may a court look beyond the terins of his will to learn, for example, the size of his estate, the size of the trust estates, the relationships he enjoyed with his children, grandchild, and new spouse, and whether the new spouse was otherwise provided for?

Suppose that the first wife's will was probated im New York and her trusts were administered there. Under the traditional choice of law rule, New York law would determine whether the husband had exercised either of his powers, even though the husband may have resided in California and executed his will in Texas. Under New York law, his will would execute both powers, and no evidence outside of the will would be admissible to show that he did not intend to exercise either or both. Thus, the second wife and grandchild would take all of the trust assets to the exclusion of the children. On the other hand, if the first wife's will was probated in Maryland or Michigan and established testamentary trusts in either of those states, the husband's will would not exercise the general power, and no evidence outside of his will would be admissible to show that he intended to provide for his wife or grandchild from the marital deduction trust. The husband's will would not exercise the special power unless the court found from extrinsic 
evidence that he intended to exercise it in favor of the grandchild. If California law apphed, the basic assumptions would be that the husband's will exercised the general power and did not exercise the special power. However, extrinsic evidence would be admissible with respect to both powers to show that he intended the contrary result. The result would also be different if the wife's will was governed by the law of Rhode Island, which has a statute based on the English model, or by the law of New Jersey, a common law state with the liberal standard, or by the law of Connecticut, a common law state with the conservative standard.

The variety and complexity of the rules applied by the various states, when combined with the likelihood that the donee's attorney will not correctly anticipate which state's law will be applied, have created a situation that inevitably breeds litigation, frustrates expectations of beneficiaries, and provides ample opportunity for legal malpractice. ${ }^{275}$ The costs imposed by the variety of state rules clearly outweigh any possible advantages derived front their diversity. Given the mobility of today's population, the increasing emphasis on reducing the transaction costs of transmitting property at death, and the increasing use of powers of appointment, ${ }^{276}$ a better approach must be found. The only satisfactory solution will be a single rule that gives maximuni opportunity to carry out the actual intent of the donee, apphed uniformly throughout the United States. A uniform act would be ideal.

In fashioning a uniform rule on the exercise of powers by general dispositions or residuary clauses, three principal points must be resolved: the basic assumption as to the donee's probable intent; permissible sources of evidence of actual intent contrary to the basic assumption; and the standard to be applied in determining whether that evidence is sufficient to overcome the basic assunption.

In determining which basic assumption should be inade concerning the donee's probable intent, two factors are important: whether

275. See, e.g., Farnum v. Pennsylvania Co. For Ins. on Lives \& Granting Annuities, 87 N.J. Eq. 108, 99 A. 145 (1916), affd, 87 N.J. Eq. 652, 10I A. 1053 (1917). In that case the lawyer testified that he had omitted language of express exercise because the donee's domicile was Pennsylvania, which has a statute modeled after the English version.

276. Powers of appointment will continue to be used in marital deduction trusts; and it seems likely that they will increasingly be used in other kinds of trusts, as a result of the enactment of the generation-skipping tax in the Tax Reform Act of 1976, Pub. L. No. 94-455, 90 Stat. 1520. See A. Casner \& R. Stein, Estate Planning Under the Tax Reform Act of 1976 (2d ed. 1978); R. Covey, Generation-Skipping Transfers in Trust (3rd Ed. 1978); Bloom, The GenerationSkipping Loophole: Narrowed, But Not Closed, by the Tax Reform Act of 1976, 53 WASH. L. REv. 31 (1977); Brown, A Case Against an Additional Tax on Generation-Skipping Transfers, 106 Tr. \& Est. 997 (1967); Note, Estate Planning: Effect of 1976 Tax Reform Act on the Uses of Trusts in Estate Planning, 30 OKLA. L. REv. 644 (1977). 
there is any consensus as to what the average donee probably intends, and whether one assumption or the other provides a more workable basic position. With respect to the first consideration, courts and legislatures take diametrically opposed positions. On one side, unany states follow the common law position that a donee who intended to exercise the power would probably have inentioned the power. Most people holding powers do not speak of the assets subject to the power as simply "iny property" or "iny estate." On the other side are those states following the 1830 s reforms, which were based on the idea that property subject to a power is not likely to be distinguished from property owned by the donee, and the words "iny estate" are likely to be intended to refer to the appointive assets. This position, of course, only makes sense in reference to property subject to general powers. ${ }^{277}$ Professor Rabin has argued, in support of an assunption favoring exercise, that all testators, including the donees of powers, want to dispose of as inuch property as they possibly can by their wills, and that donees intend to exercise all powers they hold. ${ }^{278}$ Others argue to the contrary, particularly when the donee holds the power under a marital deduction trust. ${ }^{279}$ There is no consensus as to what most donees probably intend, and it seems fair to say that donees fall into both eamps: some intend to exercise their powers and some do not. Because there is no good reason for preferring one or the other of these assumptions on the ground that it inore accurately reflects the intent of most donees, other factors should be considered.

The determining factor in selecting the base-point assumption should be simplicity. In states with assumptions favoring exercise, legislatures and courts have often felt the need to distinguish between general and special powers. There are two reasons for this distinction: first, that the assumption favoring exercise rests on the similarity between the power and ownership, and special powers are not likely to be confused with outright ownership; and second, that exercise of special powers by residuary clause is often likely to cause difficulty when the takers nained in the residuary clause are not permissible appointees of the power. ${ }^{280}$ In contrast, an assuinption against exercise avoids en-

277. A special power, of course, permits appointment only among the objects specified by the donor. The donee occupies a position clearly different from that of an owner of property.

278. Rabin, supra note 126 , at 2.

279. See, e.g., UNIForm Probate Code § 2-610 comment; Effland, Powers of AppointmentThe New Wisconsin Law, 1967 WIS. L. REv. 583, 597-99.

280. Under some wills, of course, there would no rooin to argue that a donee intended to exercise a special power, even if it could be argued that the same will would have been intended to exercise a general power. This would occur where the takers under the donee's will were not objects of the power. Where the beneficiary of the donee's will is an object of the power, however, 
tirely the question whether a distinction should be drawn between general and special powers. In addition, where the basic assuinption favors exercise, the careful drafter of the donor's instrument requires a specifie reference to the power to prevent madvertent exercise. Where the basic assumption is against exercise, however, the specific reference clause is unnecessary except to prevent blanket execution of the power. Thus, a basic assumption that the donee does not intend to exercise the power promotes simplicity and consequently reduces the chance of drafting errors.

The reason for the dramatic shift in basic assumptions made by the reforin statutes of the 1830 s was that the cases had produced results that often frustrated the intent of donees. The solution was to provide that donees did exercise powers by residuary clauses. The real problein, however, lay not with the basic assumption, but with the exclusion of almost all evidence of any contrary intent. Had the courts been willing to consider and act on rehable evidence of the donee's intent, the basic assumption made should not have created any severe problems. As long as the donee's actual intent can be effectuated when it is fairly apparent, the results of the cases cannot appear as unjust as those of the early 1800 s or those under the reform statutes. A uniform solution to this problem, then, should clearly incorporate the rule of the modern common law that all relevant and otherwise admissible extrinsic evidence of the donee's intent should be admissible to overcome the basic assumption made. Although this position would simply bring the law on exercise of powers into conformity with the law on interpreting wills generally, the statute should cover this point explicitly to prevent the courts from returning to the old English precedents. ${ }^{281}$ The inodern law on interpretation of wills is not unform on the question whether and under what circumstances the testator's declarations of intent should be adinitted. The need for uniformity, however, does not extend to the point that there must be a uniform rule on the admissibility of direct declarations of the testator's intent. Here, the individual states could safely be left to apply whatever rule they apply to the interpretation of wills generally, without coinpromising the overall objective of having a simple and uniform rule on the exercise of powers by general dispositions or residuary clauses.

The last point that should be resolved by the uniform statute is the standard to be applied in determining whether there is sufficient evi-

there seems no sensible basis for saying that if the power was general he intended the beneficiary to take, while if it was special he did not.

281. See Leidy Chems. Foundation, lnc. v. First Nat'l Bank, 276 Md. 689, 351 A.2d 129 (1976); Hund v. Holmes, 395 Mich. 188, 235 N.W.2d 331 (1975). 
dence of a contrary intent to overcome the basic assumption made as to the donee's intent. The standards currently applied range from one requiring conclusive evidence of a contrary imtent, ${ }^{282}$ to one requiring clear and convincing evidence of a contrary intent, ${ }^{283}$ to one requiring only a preponderance of the evidence of a contrary intent. ${ }^{284}$ Since strong arguments can be made for both basic assumptions-that the donee does intend or does not intend to exercise his power-it seems rcasonable to say that in any given case the donee might have intended either result. Tlius, any credible evidence that the donee did intend to exercise the power should be given effect: preponderance of the evidence in favor of exercise should be the standard. The practical result of this standard is that the basic assumption agamst intent to exercise will operate only when there is no credible evidence to the contrary.

In summary, a satisfactory solution to the problem of determining when a general disposition of property in the donee's will exercises a power would be provided by a uniform act containing the following: a basic presumption that the donee does not intend to exercise any power by a general disposition of property or a residuary clause, a statement that extrinsic evidence of a contrary intent is adnissible, and a statement that if a preponderance of the evidence shows a contrary intent, the donee's will will be held to exercise the power.

Section 2-610 of the Uniform Probate Code meets two of these three criteria, providing:

[A] general residuary clause in a will, or a will inaking general disposition of all of the testator's property, does not exercise a power of appointment held by the testator unless specific reference is made to the power or there is some other imdication of intention to imclude the property subject to the power. ${ }^{285}$

The one missing element is an articulation of the standard to be applied in determining when there is sufficient indication of an intent to exercise. The standard could be spelled out in the Comment to the section, ratler than being incorporated into the statute itself. Since the Comment is currently confusing ${ }^{286}$ and ought to be rewritten in any event, a new Comment specifying the liberal preponderance standard of Bank of New York would make tlie Uniform Probate Code provision a satisfactory solution to the problen1 of determining when the donee's will exercises a power by a residuary clause or otlier general disposition of property. States that do not intend to enact the Code as a whole

282. Andrews v. Emmot, 29 Eng. Rep. 162 (Ch. 1788).

283. Blagge v. Miles, 3 F. Cas. 559 (C.C.D. Mass. 1841) (No. 1,479).

284. Bank of N.Y. v. Black, 26 N.J. 276, 139 A.2d 393 (1958).

285. UNiform Probate Code $§ 2-610$.

286. See text accompanying note 231 supra. 
should follow the lead of Oregon ${ }^{287}$ and Massachusetts ${ }^{288}$ by enacting only section 2-610. Adoption of this statute throughout the United States would eliminate a significant risk currently involved in using powers of appointment. ${ }^{289}$

287. OR. Rev. STAT. \& 112.410 (1975).

288. Mass. Gen. Laws ANN. ch. 191, $\S 1$ IA (West Cum. Supp. 1978-79).

289. Such risks may, of course, also be eliminated by uniform judicial decisions. In those states without statutes, courts should adopt the position taken by the statute, which is in fact modeled on the common Iaw of New Jersey and Illimois. Upon enactment this statute should be governed by the usual rule on retroactivity: it should apply to the will of any decedent dying after its effective date. See, e.g., UNIFOrm Probate Code \& 8-101(b)(1). 